\title{
THE ECONOMIC FOUNDATIONS OF PoliticAl CONFLICT IN BALI, 1950-1965
}

\author{
Geoffrey Robinson
}

\section{Introduction}

Surveys of modern Balinese history are curiously silent on the dramatic economic changes which occurred in the period 1950 to $1965 .^{1}$ They provide virtually no detailed description or analysis of the poverty, hunger, and spiralling inflation which gripped Bali during these years. Moreover, in contrast to the scholarly energy devoted to such issues in Java, we do not yet have any meaningful analysis of changing rural relations of production in Bali, of the dynamics of land reform, or their implications for political conflict there. ${ }^{2}$ The gap in our knowledge is, in part, the result of the continued dominance of a tradition in the study of Bali which emphasizes the significance of culturally specific bases of affiliation rather than those of class. This approach has, I think, helped to obscure the nature of political conflict in this period, and has seriously impaired attempts to understand the internecine violence of $1965 / 66 .^{3}$

\footnotetext{
This article is a revised version of a chapter from my PhD dissertation, "The Politics of Violence in Modern Bali, 1882-1966," PhD dissertation, Cornell University, 1992. In order to protect relatives and friends, only the initials of alleged PKI sympathizers or members are given here.

1 Virtually the only work which treats Bali's economy during these years in any depth is I Gusti Gde Raka, Monografi Pulau Bali (Jakarta: Djawatan Pertanian Rakjat, 1955). More recent economic surveys of Bali pay scant attention to the early post-independence period. See, for example, I.K.G. Bendesa and I. M. Sukarsa, "An Economic Survey of Bali," Bulletin of Indonesian Economic Studies 16, 2 (July 1980); R. Daroesman, "An Economic Survey of Bali," Bulletin of Indonesian Economic Studies 9,3 (November 1973); and Mark Poffenberger and Mary Zurbuchen, "The Economics of Village Bali: Three Perspectives," Economic Development and Cultural Change 29 (October 1983). Of the small number of general works which deal with the period, most refer only in passing to economic issues.

2 On rural class relations in Java see, for example: W. F. Wertheim, "From Aliran to Class Struggle in the Countryside of Java," Pacific Viewpoint 10 (1969); Rex Mortimer, "Class, Social Cleavage and Indonesian Communism," Indonesia 8 (October 1969): 1-20; and idem, The Indonesian Communist Party and Land Reform, 1959-1965 (Clayton, Victoria: Centre for Southeast Asian Studies, Monash University, 1972); and Benjamin White, "Rural Resistance After the Destruction of a Peasant Movement: Java Since 1966" (photocopy), April 1984.

3 Political and methodological difficulties have also played their part. The disappearance of vast quantities of written documents in the aftermath of 1965 , and the tragic death of tens of thousands of suspected Communists
} 
This article seeks to examine the common assumption that economic factors and class have not been important bases of political affiliation and conflict in Bali. It does so by focusing on three related dimensions of the problem. First, it outlines the relationship between economic conditions and patterns of political mobilization, describing how the hyperinflation of the early 1960s, together with a series of natural catastrophes, helped to shift political attitudes and to accelerate political conflict in the final years of the Old Order. Second, it analyzes the role of the local state apparatus and political party networks in shaping Bali's economy and thereby also in structuring political relations in Bali. It shows how local state and party involvement in the distribution of economic resources from the center, the creation of a Balinese capitalist class, and the implementation of land reform, encouraged political conflict among Balinese, and increasingly along class lines, rather than focusing attention against the center. Finally, the article examines explicitly the relative significance of class and other socio-cultural groupings as bases of political affiliation and conflict. It argues that class became increasingly salient in Bali after 1963 when the PKI began to pursue a more militant class-based strategy in the implementation of land reform.

\section{Economic Crisis and Political Mobilization}

In a political report from July 1950 the Dutch Bali-expert, Ch.J. Grader, argued that heightened expectations generated by the National Revolution had made economic development one of the most pressing political issues facing the new government in Bali. ${ }^{4}$ Great expectations, however, could scarcely be met in the first years of Indonesian independence. Serious crop failures (rice and coffee) in 1949/50, shortages of imported basic necessities (cloth, sugar, rice), and a lack of confidence in the Republic's paper currency during the Revolution, had contributed to spiralling inflation in Bali. ${ }^{5}$ In June 1950, the price of rice in Singaraja was Rp. $1.75 / \mathrm{kg}$, already higher than in other parts of the country. ${ }^{6}$ By February 1951 , it had risen to Rp. $2.35 / \mathrm{kg}$ and the shops were virtually empty. In the first week of 1952, the price had jumped once again to Rp. $3.50 / \mathrm{kg} .{ }^{7}$ while the average wage for a laborer

in Bali alone, make the period 1950-1965 very difficult to document or analyze. The problem is compounded by the fact that it remains a serious crime in Indonesia to have any link with the Communist Party (PKI), so that few people wish to discuss the period openly, still less to admit any deep knowledge of the party. Writing an account of this period, therefore, requires the reconstruction of events on the basis of fragments of information from interviews, national and local newspapers, and occasional government documents. For further details of the coup and its aftermath in Bali, see Robinson, "The Politics of Violence in Modern Bali," ch. 12, and Robert Cribb, ed., The Indonesian Killings of 1965-1966: Studies from Java and Bali (Clayton, Vic: Monash Papers on Southeast Asia no. 21, 1990).

${ }^{4}$ He wrote of "... the necessity of taking measures in the interest of economic development, given that the revolutionary period has created great expectations in this area." Ch. J. Grader, "Bali, Tournee-Aantekeningen, Juli 1950," Collectie Korn, OR 435-23 (Koninklijk Instituut voor Taal-, Land-en Volkenkunde, Leiden fhereafter KITLV]).

${ }^{5}$ Grader wrote: "That the cost of living is among the highest in all of Indonesia is in good part a result of the fact that there are insufficient imports compared to the high spending power made possible by exports." In "Persatuan Tenun Indonesia," Collectie Korn, OR 435-23, KITLV. Inflation seems to have been worsened by the sudden increase in the silver money supply (f 30 million) with the Dutch reoccupation of Bali in 1946 . Ch. J. Grader, "Credietbehoefte ten Plattelande," Collectie Korn, OR 435-23, KITLV. The problem was compounded by the discrepancy in the exchange value of paper and silver currency; the price of goods if bought with paper currency was three or four times the price with payment in silver coin.

6 Letter from Grader to Korn, June 18, 1950, Collectie Korn, OR 435-59, KITLV.

7 "Bali Gontjang Karena Beras," Suara Rakjat, January 8, 1952. 
in the town remained at Rp. $1.50 /$ day. $^{8}$ Particularly for those without land of their own, and for wage employees in the towns, basic necessities became increasingly difficult to obtain. ${ }^{9}$

It was hardly surprising, under conditions such as these, that there were dramatic increases in thefts of basic foodstuffs-especially rice and cassava-and in a variety of other economic crimes. The connection was not lost on contemporary observers. One newspaper article commented:

In these times the people of Bali are distraught on account of the increasingly brazen acts of banditry and theft. The disruption of the peace is primarily related to the increase in the cost of food. Not simply rice, but other foods as well have all increased in price. ${ }^{10}$

The shortages were reportedly worst in Buleleng-which traditionally relied for much of its rice on Tabanan-and it was in Buleleng that the robberies and the banditry were most serious.

Economic difficulties also led to a quickening of political mobilization in Buleleng, where there already existed a relatively large and militant body of migrant agricultural laborers-employed principally in coffee plantations-and unionized urban workers. Singaraja was in fact the site of Bali's first modern industrial action, in 1950. Harbor workers of the transport company ESSER stayed out on strike in Buleleng for nearly two months, demanding wage hikes in line with inflation. The company refused to raise wages above those set for Surabaya, where the cost of living at this time was considerably lower. These conditions helped leftist political parties and organizations, like IRMI (Ikatan Rakjat Murba Indonesia) and Partai Buruh, develop an early following in Buleleng. ${ }^{11}$

Prices on essential goods were held in check by local government controls through the mid-1950s, but the problems of inflation and the shortage of basic necessities surfaced once again after 1956. In 1957, for example, a combination of poor local harvests, bottlenecks in the distribution of imported stocks, and speculation, gave rise to sudden price increases for rice, from a normal rate of Rp. $3.50 / \mathrm{kg}$. to Rp. $7.50 / \mathrm{kg} .{ }^{12}$ It was only in the $1960 \mathrm{~s}$, however, that inflation reached crisis proportions, and began to have clear social and political ramifications throughout the island (see Table 1). Hyper-inflation affected both the urban and rural population, though in slightly different ways. Workers on fixed wages or salaries, such as teachers and factory-workers, suffered a constant and disastrous decline in real earnings

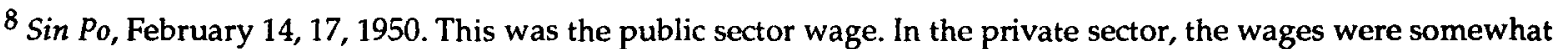
higher, at Rp. 2/day. Of course, not all work was paid for in wages. Agricultural laborers sometimes received a percentage of the harvest instead. In parts of Buleleng, for example, rice harvest laborers received between $1 / 25$ and $1 / 13$ of the yield. For further examples of wage rates at this time, see Made Netja, "Pemeriksaan Agronomi Dalam Distrik Tedjakula 1949-1950" (Singaraja: n.p., 1951). For wage rates in Bali's coffee growing regions, see Komang Tjawi "Laporan Mengenai Daerah Kopi di Banjuatis, Munduk, Gobleg, Gesing, dan Umedjero" (Singaraja: Kantor Inspeksi Kooperasi Buleleng, 1952).

9 "Bali Kekurangan Makanan," Suara Rakjat, February 4, 1952.

10 Sin Po, February 14, 1950.

11 Letter from Grader to Korn, September 7, 1950 Collectie Korn, KITLV. Unions active in Bali by 1957 included KBSI, SOBSI, KBKI, GBI, and SBII. For figures on unionization in Bali up to 1957, see Sarimin Reksodihardjo, Memorie Penjerahan Gubernur, Kepala Daerah Propinsi Nusa Tenggara 1/4/52 - 30/3/57 (Singaraja: n.p., n.d.), p. 198. 12 Suara Indonesia (Denpasar), October 25, 1957. There were also reports of severe malnutrition and starvation at this time. Suara Indonesia (Denpasar), November 11, 1957. A 1956 report on employment conditions in Bali painted a rather pessimistic picture of local economic prospects: "Rapid population growth and growing pressure on agricultural land, without any real development in the fields of trade, finance and industry, will most certainly lead to greater poverty in the coming years." Tindjauan Pasar Kerdja Daerah Nusa Tenggara Barat Tahun 1956 (Denpasar: Kantor Penempatan Tenaga Daerah Nuteng Barat, 1957), p. 41. 
after about $1957 . .^{13}$ In rural areas, rapid inflation-and the diminishing value of cash and savings which this implied-meant that real assets, such as agricultural land and produce, became even more valuable than usual. This probably helped landowning peasants, and those who produced a surplus, to pay off old debts. However, rural dwellers who were net consumers and wage-earners, were harder hit. As the cost of basic daily needs and agricultural inputs-food, fertilizer, tools etc. $\rightarrow$ soared, marginal peasants with no surplus to sell, and therefore limited cash income, must have fallen increasingly into debt. Landless agricultural laborers, like wage-laborers in urban areas, also suffered a decline in real earnings with inflation. ${ }^{14}$

Table 1. Rice Prices in Bali 1950-1964

(Rupiah per Kg.)

\begin{tabular}{cc|lc}
\hline \hline Date & Price & Date & Price \\
\hline 1950 & 1.75 & 1960 & 12.00 \\
1951 & 2.35 & 1961 & 18.00 \\
1952 & 3.50 & Jul. 1962 & 27.00 \\
1953 & 3.50 & Dec. 1962 & 30.00 \\
1954 & 3.50 & Apr. 1963 & 40.00 \\
1955 & 3.50 & Jun. 1963 & 60.00 \\
1956 & 3.50 & Oct. 1963 & 85.00 \\
1957 & 7.50 & Nov. 1963 & 125.00 \\
1958 & 8.00 & 1964 & 130.00 \\
1959 & 11.00 & & \\
\hline
\end{tabular}

Sources: Suara Indonesia (Denpasar), "Harga Pasar," 1962, 1963; "Menutup Tahun 1964," January 1, 1964; "Orientasi Beras," October 23, 1963; Suara Rakjat, "Bali Gontjang Karena Beras," January 8, 1952.

From 1957 to mid-1962 the price of rice in Bali increased fourfold to Rp. $27 / \mathrm{kg}$., and thereafter even more dramatically, reaching Rp. $130 / \mathrm{kg}$. by 1964 . Even when massive infusions of rice from the center temporarily leveled out rice prices in 1964, the cost of other basic necessities continued to rise. ${ }^{15}$ Moreover, wage increases lagged seriously behind inflation. In 1962, for example, the official minimum wage in the local canning factory was Rp. 8.50/day, or enough to purchase just over a quarter of a kilogram of rice. ${ }^{16}$ Though no reliable figures are available, it is safe to say that wages for part-time day labor-construction and coolie-work-were considerably lower than this.

The political problem of inflation was exacerbated in Bali by the central government's policy on rice distribution. Substantial infusions of rice (as well as other basic necessities like

13 See, for example, "6 Guru S.R. Tinggalkan Tugas Karena Gadji Tak Tjukup," Suara Indonesia (Denpasar), December 5, 1962. This article reports that the average salary for an elementary school teacher in Bali was Rp. $500 /$ month, while one months' worth of rice cost roughly Rp. 1,000.

14 Ina Slamet writes that "... living conditions were seriously deteriorating at the time through inflation (steeply rising prices for necessities that had to be bought, including food for marginal peasants and agricultural laborers), rat plague and drought." Ina Slamet, "Views and Strategies of the Indonesian Peasant Movement on the Eve of its Annihilation in 1965-1966" (photocopy, 1984).

15 "Menutup Tahun 1964," Suara Indonesia (Denpasar), January 1, 1965.

16 Indonesia, Departemen Perindustrian dan Pertambangan, Monografi Daswati I Bali 1961 (Jakarta, 1962), pp. 6061. 
sugar, cloth, and cement) were intended, it was said, to act as a brake against inflation, but the mechanism used did not benefit all Balinese equally. "Injection rice," that is subsidized rice from the central government, was sold to civil servants and military personnel at far below market prices. In 1962, for example, when the average price for a kilogram of rice in Bali was Rp. 30, civil servants were able to purchase it for just Rp. $5 / \mathrm{kg}$. At the same time Bali's producers were required (until 1963) to sell a proportion of their rice to the government at the artificially low price of $\mathrm{Rp} .6 / \mathrm{kg}$, but they were not able to purchase rice for consumption at the subsidized rate. ${ }^{17}$ Effectively, the government's system of rice purchasing and distribution favored a segment of the town-dwelling consumers at the expense of rural producers and laborers, and signified an effort to avoid the political difficulties which might arise from an alienated urban sector. ${ }^{18}$

A local newspaper report from 1963 noted that serious shortages, and wild increases in the price of rice in recent months had meant that:

... in the villages people are increasingly having to mix their rice with banana and coconut pulp and papaya leaves, at a ratio of about 1:3 or 1:4. Indeed many are at the point where they are eating only banana pulp and leaves, with no rice whatsoever. ${ }^{19}$

Even in villages which produced a rice surplus, poor peasants were eating little or no rice. ${ }^{20}$ Reports of death from starvation and widespread malnutrition became increasingly common in the local press after 1963, though the importance of preserving the image of "fertile" harmonious Bali meant that coverage of such reports in the national media was limited.21

The grave economic conditions of the early 1960s were compounded by a succession of rat and mouse plagues, insect infestations, and crop failures between 1962 and 1965, and, perhaps most importantly, by the volcanic eruption of Gunung Agung in early 1963.22 Though it had earlier begun to show signs of activity-smoking, shaking, and spewing small amounts of lava-Gunung Agung erupted seriously for the first time on March 17, 1963, and then again on May $16 .^{23}$ The eruption claimed an estimated 1,500 lives, took more than 62,000 hectares of land out of production, meant severe malnutrition for over 10,000

17 Suara Indonesia (Denpasar), December 4, 1962.

18 In 1956 there were an estimated 2,500 civil servants in Bali, not including teachers, of whom there were 2,208. See Tindjauan Pasar Kerdja, pp. 32-34.

19 "Harga Beras Semakin Menggila," Suara Indonesia (Denpasar), October 22, 1963.

20 Ina Slamet, who shared responsibility for organizing a series of village studies conducted by PKI cadres in Java and Bali in early 1965, cites the example of the village of Singakerta in Gianyar which, in 1965, produced a surplus of rice, but whose poorer peasants ate a 5:1 cassava-rice mixture. The findings of the various village studies, and Slamet's analysis of the information, can be found in her as yet unpublished work, "Views and Strategies of the Indonesian Peasant Movement," p. 94. Also see, "Rakjat Mulai Makan Ketela Melulu: Panen Gagal, Tikus Mengganas," Suara Indonesia (Denpasar), September 18, 1962.

21 In the local press, see, for example: Suara Indonesia (Denpasar); “Nusa Penida Kering-30,578 Orang Terantjam Bahaja Kelaparan," August 2, 1963; "22 Orang Penderita Busung Lapar Meninggal, 460 Orang Dirawat," August 14, 1963; "Saat2 Mendjelang Hari Raja Galungan," May 11, 1964.

22 See, "Gerakan Masaal Membasmi Tikus," Suara Indonesia (Denpasar), January 29, 1963; and "Daging Tikus Tidak Membahajakan," ibid., January 31, 1963.

${ }^{23}$ On the eruption, see Windsor P. Booth and Samuel Mathews, "Disaster in Paradise," National Geographic 124, 3 (September 1963): 436-58; and Anna Matthews, The Night of Purnama (Kuala Lumpur: Oxford University Press, 1983). 


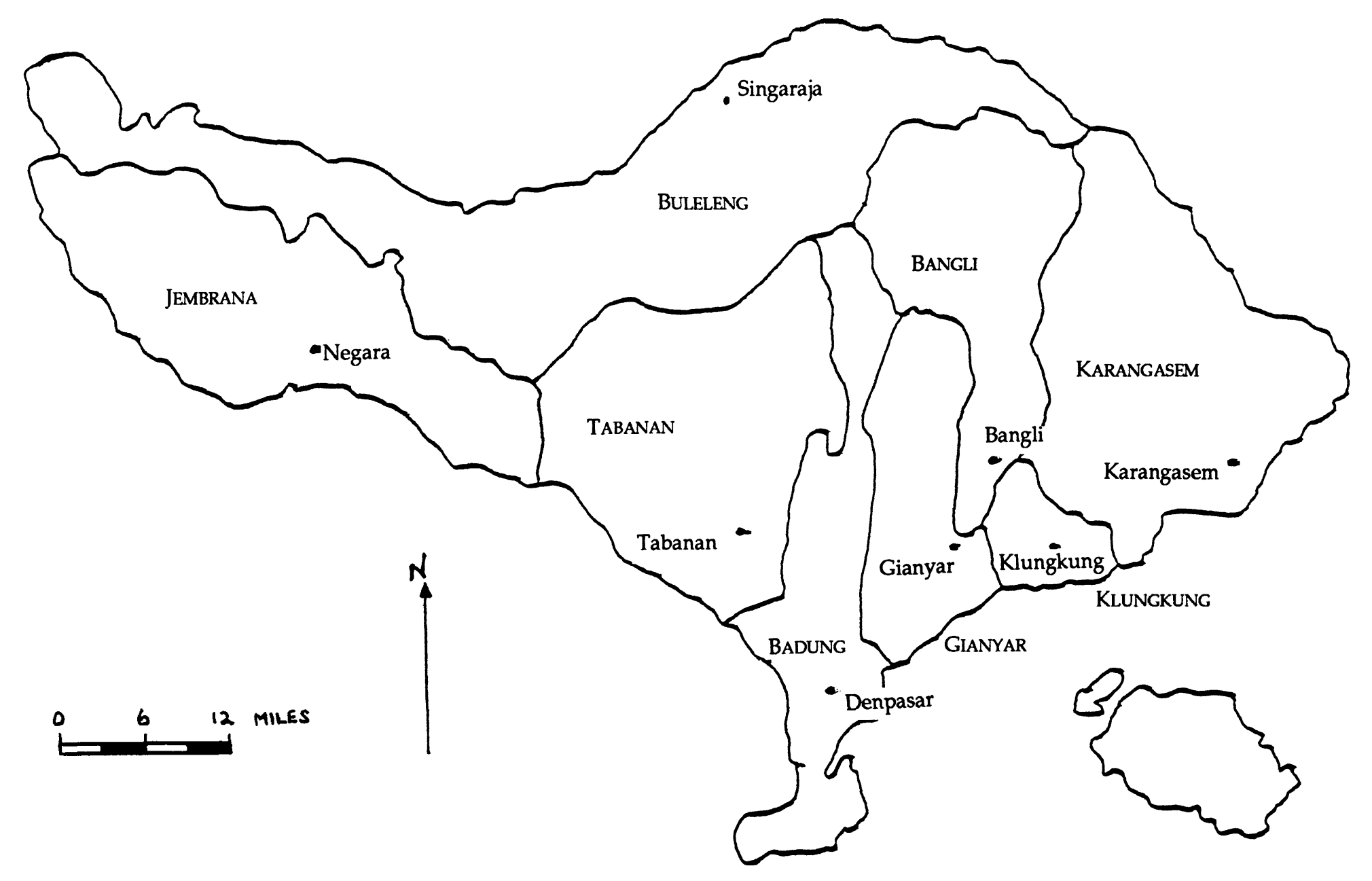

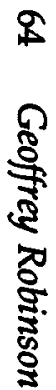

Bali's Eight Kingdoms 
and caused the exodus of as many as 75,000 people to neighboring principalities. ${ }^{24}$ The most seriously affected areas were those in the eastern part of the island where Gunung Agung lies: Karangasem, Klungkung, Bangli, and Gianyar. Refugees from these areas generally crowded into the larger towns of Denpasar and Singaraja, where, together with the existing urban poor, they formed an underclass ripe for mobilization by the increasingly active mass organizations (ormas).

According to official statistics, the number of urban wage-laborers in Bali was minuscule; in 1956, only 5,445 persons were employed in businesses with more than ten employees. ${ }^{25}$ However, the actual number relying on wage labor, both in the towns and the rural areas, may be estimated conservatively to have been several times this number. Even in relatively prosperous times there were, for example, tens of thousands of migrant laborers employed each year in the coffee harvest in Buleleng, Tabanan, and Bangli. There were also untold numbers who worked seasonally or part-time on construction projects, as harborlaborers and in businesses with fewer than ten employees, none of whom appeared as wage-laborers in official statistics. In view of the fact that wages failed to keep pace with inflation, the number of poor wage-earners in the early 1960 s must already have been quite substantial. After the eruption of Gunung Agung, the ranks of urban poor and unemployed swelled astronomically. A newspaper report from October 1963 observed that:

The number of beggars in the towns is increasing every day. They are leaving their home villages which are suffering economic shortages and coming to the towns to beg. ${ }^{26}$

The massive movement of internal refugees-delicately termed "urbanization" in government documents-contributed to serious social and economic problems in the towns, including unemployment, rising crime rates, and prostitution. ${ }^{27}$ The 1963 annual report of the Bali office of the Department of Labor, for example, estimated that roughly 30 percent of Bali's adult labor force was unemployed in that year, compared to an estimated rate of 14 percent in $1956 .^{28}$ Though no precise figures are available for criminality, reports of theft (especially of food) and unruly behavior were increasingly common after 1960, both in the media and in government reports. ${ }^{29}$ There was, moreover, an increase in anti-Chinese activ-

\footnotetext{
24 All figures are from a report (dated May 3, 1963) by the Head of the Protestant Church of Bali, Ds. K. Suwetja. Casualty estimates were made by local Red Cross teams and by Dr. Made Djelantik. The estimates of the local KoOGA - the government organization with responsibility for handling the disaster-were considerably higher. In October 1963, it reported 98,792 internal refugees, 15,595 suffering severe malnutrition (busung lapar) and 122,743 in serious danger of malnutrition (terantjam busung lapar). See Suara Indonesia (Denpasar), October 21, 1963. Governor Sutedja estimated that 25,000 ha. of land had been permanently ruined, and that 100,000 ha. would be unproductive for many years to come. On the number of refugees, as of April 1963, he said "We have to feed 85,000 refugees and we simply have not the food to do it." See "Disaster in Paradise," National Geographic, pp. 454-55.

25 See Monografi Daswati I Bali, p. 8.

26 "Harga Beras Semakin Menggila," Suara Indonesia (Denpasar), October 22, 1963.

27 Even prior to the eruption of Gunung Agung, rapid population growth was contributing to the pressure on agricultural land. Average population density in Bali (1961) was 358 persons $/ \mathrm{km}^{2}$; the density was highest in Gianyar $\left(632 / \mathrm{km}^{2}\right)$, followed by Badung $\left(572 / \mathrm{km}^{2}\right)$, Bangli $\left(393 / \mathrm{km}^{2}\right)$, Tabanan $\left(321 / \mathrm{km}^{2}\right)$, Karangasem $\left(304 / \mathrm{km}^{2}\right)$, Klungkung $\left(246 / \mathrm{km}^{2}\right)$, Buleleng $\left(245 / \mathrm{km}^{2}\right)$, and Jembrana (154/ $\left.\mathrm{km}^{2}\right)$. Monografi Daswati I Bali, p. 6 . When calculated as a percentage of productive land, the densities were markedly higher.

28 A 1956 government report estimated that roughly 200,000 of a total labor force (men and women aged 14 to 60 ) of about 1,400,000 were unemployed. The most serious unemployment problem was in the towns of Singaraja, Denpasar and Tabanan. Tindjauan Pasar Kerdja, pp. 35-39.

${ }^{29}$ See, for example, "Komplotan Perampok di Djemberana Terbongkar," Suara Indonesia (Denpasar), March 16, 1964.
} 
ity, which in Bali, as in other parts of Indonesia, was one of the more common manifestations of economic and social discontent. ${ }^{30}$

Economic crisis and concomitant social changes after 1963 appear to have contributed not only to intermittent unrest and rising criminality, but also to the popularity of parties of the left, such as the PKI, IRMI, Partai Buruh, and Partindo. ${ }^{31}$ In Denpasar and Singaraja, for example, hamlets with strong PKI bases-e.g., Suci, Kerenceng, Titih, and Ubung in Denpasar, and Banjar Java in Singaraja-had sizeable populations of migrants and workers. Already the third most popular party in Bali in 1955, the PKI (and other leftist parties) and its various mass organizations, by all accounts, experienced a second major wave of expansion in Bali after 1963.32 The uprooted and the dispossessed-or more precisely, wageearners, migrants, and unemployed-both in the towns and in rural areas, constituted a considerable proportion of the population of Bali by the end of 1963, and they provided fertile soil for the mobilization of the mass organizations which, stimulated by developments at the national level, became increasingly militant at precisely this time. ${ }^{33}$

\section{The Political Economy of Dependency and the Rise of Bali's Capitalists}

Well known for the fertility of its soils and the sophistication of its system of wet-rice agriculture, Bali nonetheless relied heavily upon imports to supplement basic needs in the post-independence period. Local rice production had fallen so far short of local consumption requirements that by 1962, Bali was relying on monthly "injections" of 300 tons of rice per month from the central government. ${ }^{34}$ In the same year, the provincial legislature (DPRD-GR-Bali) sent a delegation to Jakarta to request that the government rice-purchase target for Bali be reduced by 50 percent, and called for further increases in "injection rice" from the center. ${ }^{35}$ After the eruption of Gunung Agung in April 1963, the shortage became

${ }^{30}$ For examples of anti-Chinese activities in the towns, see Suara Indonesia (Denpasar): "Tjegah Tindakan Gedjala2 Rasial di Bali," June 19, 1963; "Pelakat2 dan Surat2 Kaleng," June 15, 1963.

31 For a more detailed analysis of political party growth and competition in Bali from 1950 to 1965, see Robinson, "Politics of Violence in Modern Bali," ch. 11.

32 There were no comprehensive elections during this period, but scattered results from local elections for Perbekel indicate strong support for the PKI and Partindo. One such result was the election of a PKI Perbekel in the former Republican base area of Sukasade, Buleleng. Moreover, press reports of the creation of new PKI-affiliated ormas branches, show a similar pattern of rapid expansion after 1963.

33 Political polarization and militancy at the national level were also accelerated by the nationalization of Dutch plantations beginning in 1957, and the land-reform legislation of the early 1960s. Military control of plantations after 1957 placed disputes over wages and working conditions into sharper relief, providing the groundwork for political conflict between the military and agricultural laborers. Plantation workers were historically among the most militant in Indonesia's rural sector, while the economic benefits which accrued to the military assured that it became a staunch defender of the status quo. More significant for Bali, however, was the national land-reform legislation which mandated the redistribution of land and dramatic changes in harvest-sharing arrangements. This legislation is discussed in detail below.

34 Even this amount was considered to be insufficient to meet actual needs. In September 1962, Governor Sutedja requested a further 200 tons per month, for a total of 500 tons per month, or 6,000 tons per year. Suara Indonesia (Denpasar), September 27, 1962. In 1961, at least four of the eight kabupaten in Bali-Klungkung, Karangasem, Bangli, and Buleleng-were rice deficit areas. The government report which cited these statistics acknowledged that they overestimated the actual availability of rice in Bali, and suggested that, even as early as 1961, the entire island was a deficit area, with the possible exception of Tabanan. See Monografi Daswati I Bali 1961, p. 29.

35 Suara Indonesia (Denpasar), September 14, 1962. 
so serious that Bali was granted a full exemption from obligations under the government rice purchase system. ${ }^{36}$

Bali's reliance on infusions of basic goods was part of a more general pattern of financial dependence on the center, a dependence which became acute after 1956, when national inflationary trends together with mounting local government expenditures combined to produce a growing deficit. ${ }^{37}$ Deficit financing was appealing to local state officials because it allowed them to avoid making the politically dangerous economic decisions-such as cutting civil-service wages or reducing the number of public works projects-which local revenue constraints might have necessitated. Bali's revenue dependence worsened with the decline of the island's economy in the early 1960s. ${ }^{38}$ The problem of revenue dependence was accentuated by the 1951 Land Tax exemption, one of the first pieces of legislation to have been enacted by Bali's new Republican-dominated legislature (DPRD). Apparently in an effort to win broad popular support for Indonesia's new Republican government, the law exempted a large number of Bali's peasants from the payment of land tax. At the same time, however, it deprived the local state government of what, in colonial times, had been, after opium, its largest single source of revenue.

Table 2. Bali's Budgets and Central Government Subsidies, 1951-1961 (in 000s Rupiahs)

\begin{tabular}{cccrr}
\hline \hline Year & Revenues & Expenditures & Deficit & Subsidies \\
\hline 1951 & 10,174 & 17,727 & 7,553 & 8,126 \\
1952 & 13,978 & 21,978 & 8,000 & 11,792 \\
1953 & 15,401 & 24,641 & 9,240 & 7,856 \\
1954 & 12,160 & 46,282 & 34,122 & 9,358 \\
1955 & 15,149 & 50,496 & 35,347 & 9,960 \\
1956 & 12,663 & 63,246 & 50,613 & 19,124 \\
1957 & 15,487 & 104,424 & 88,927 & 29,750 \\
1960 & - & - & 100,635 & - \\
1961 & - & - & 110,896 & - \\
\hline
\end{tabular}

Sources: Sarimin Reksodihardjo, Memorie Penjerahan Gubernur, Kepala Daerah Propinsi Nusa Tenggara, 1/4/52-30/3/57 (Singaraja: n.p., n.d.), p.56; Propinsi Nusa Tenggara, Bagian Desentralisasi, Ichtisar Keuangan Daerah Bali, Lombok, Sumba, Sumbawa, Flores dan Timor, Tahun Dinas 1951-1957 (Singaraja, 1958); Suara Indonesia (Denpasar), April 14, 1961.

Table 2 shows that between 1951 and 1961, locally generated revenues remained roughly constant, hovering between Rp. 10 and Rp. 15 million, while expenditures rose from Rp. $17,727,000$ to $\mathrm{Rp}$. $104,424,000$, producing a deficit of Rp. $88,927,000$ in 1957 . It also gives an indication of Bali's growing revenue dependence on the central government during this period, and especially after 1956 . The situation grew steadily worse in subsequent years, so

\footnotetext{
36 Suara Indonesia (Denpasar), June 2, 1963.

${ }^{37}$ In December 1950, it was agreed that the province of Sunda Ketjil (of which Bali was a part) would receive Rp. 42 million from the central government in 1951, roughly half of which would be earmarked for Bali. Sin Po, December 28, 1950.

38 From 1960 to 1962, for example, the value of exports from Bali (in constant Rupiah) declined by about 50 percent, from Rp. 50 million to Rp. 27 million. Suara Indonesia (Denpasar), December 31, 1962.
} 
that by 1964 central government contributions constituted nearly 90 percent of Bali's total revenues. ${ }^{39}$

Bali's financial dependency on the central government distinguished it from a number of other areas outside of Java-notably parts of Sulawesi and Sumatra-which were able to generate substantial local revenues through exports and smuggling. This difference was arguably the principal reason for the weakness of regionalist sentiment among Bali's politi$\mathrm{cal}$ and economic elite. One of the underlying causes of the regional discontent in Sulawesi, leading to the Permesta rebellion, was the skimming by the central government of substantial local revenues. ${ }^{40}$ This effect was most pronounced in North Sulawesi, where support for Permesta was strongest. By contrast, in South Sulawesi, which relied much more heavily on central government subsidies, support for Permesta was ambivalent, and had substantially dried up by the end of 1957. Bali was an even more extreme case. So great was the local government's economic dependence on the center that it had no incentive to demand greater autonomy. On the contrary, the only hope seemed to be to press the central government for greater outlays. This condition of increasing economic dependency meant that the main political issue in Bali concerned the distribution and control of economic goods. These were issues in which Bali's government became intimately involved.

\section{The Local State and Bali's "National" Capitalists}

A "nationalist" economic policy, involving efforts by the local state to wrest control of trade and other commerce from the Chinese, encouraged the growth of a small Balinese capitalist class in the 1950 s. ${ }^{41}$ As early as 1951, Ch. J. Grader observed:

While previously importing and a good part of retail trade were in the hands of European firms and Chinese, now the Balinese interest in these fields has grown considerably. Particularly among the younger generation, there is a trend toward cooperative endeavors. These efforts receive the full attention and support of the local government. ${ }^{42}$

This trend was spurred by the strongly interventionist economic policies pursued nationally and locally after 1953. By the late 1950s Balinese firms, with government assistance, had apparently managed to squeeze Chinese and other "foreign" businesses out of a number of key sectors, including transport, import-exporting, construction, and, increasingly, tourism. ${ }^{43}$ A government report from 1961 noted, for example, that ". . there are no foreign exporters in Bali; all are national companies which over the last fifteen years have been designated to replace the foreign businesses." 44 The same pattern was evident in the con-

39 Bali's total estimated revenues for 1964 were Rp. 1,201,554,459.00, of which Rp. 1,048,308,000.00 was to come from the central government. Propinsi Bali, Rantjangan Anggaran Keuangan Daerah Tk I Bali, Tahun Dinas 1964 (Singaraja, 1964). Also see "Daerah [Bali] Bergantung Pada Belas Kasihan Pusat," Suara Indonesia (Denpasar), October 15, 1964.

40 See Barbara Harvey, “Tradition, Islam, and Rebellion: South Sulawesi 1950-1965” (PhD Dissertation, Cornell University, 1974).

41 The office responsible for the encouragement of "national" capitalists in Bali was the Djawatan Organisasi Usaha Rakjat, in 1956 renamed the Djawatan Perdagangan Dalam Negeri dan Perekonomian Umum. Sarimin Reksodiharadjo, Memorie Penjerahan, p. 109.

42 Ch. J. Grader, "GIEB-I," in Collectie Korn, OR 435-23, KITLV.

43 See Clifford Geertz, Peddlers and Princes: Social Development and Economic Change in Two Indonesian Towns (Chicago: University of Chicago Press, 1963), pp. 22-23.

44 Monografi Daswati I Bali, p. 110. Bali's major export products were cattle, pigs, coffee, and copra. In 1961, there were 176 licensed private sector exporters, and 154 cooperatives which engaged in export activities. In the same year Bali exported 14,730 head of cattle, and 106,020 pigs. Ibid, pp. 32, 111-12. 
struction sector, which had once been monopolized by Chinese and Europeans. By the late 1950s twenty-one of the twenty-six construction firms in Bali were owned by Balinese. ${ }^{45}$ Significantly, these were the sectors over which the local state had substantial authority to grant licenses, enact protective legislation, and bestow contracts.

Clifford Geertz has identified the small group of capitalists who emerged in post-independence Tabanan as aristocrats who had been politically displaced by the transformations accompanying independence. ${ }^{46}$ Arguing that "... the dynamism of Tabanan's nobles [came] from a perceived threat to their political dominance..." he undertakes to show how the growth of modern firms after 1950 depended upon the "traditional patterns of organization and loyalty" which they were able to mobilize. ${ }^{47}$ Yet his own observations suggest a different conclusion. He writes, for example, that, in almost every case:

... the success of Tabanan's noble entrepreneurs has partly derived from their ability to gain or demand support from the local wing of the national government, and indeed, they have realized to a notable degree their aim of maintaining through economic means the substance of their local authority. ${ }^{48}$

This suggests that what distinguished the first Balinese capitalists was not their aristocratic origins per se, or their political "displacement," but rather their close political and personal links to a protectionist local state apparatus. ${ }^{49}$ Far from being politically displaced, Tabanan's entrepreneur-aristocrats had managed successfully to maintain their ties to the local state, and to turn them to good advantage after independence. ${ }^{50}$ As Geertz himself notes, "[t]he emergence, in Tabanan at least, of a unified elite of top civil servants and entrepreneurs, mainly under the aegis of the Nationalist Party [PNI], is fairly clear." 51 Elsewhere in Bali, aristocrats had similar access to the state, but they had to share the limelight with expemuda, and former civil servants of non-aristocratic background. ${ }^{52}$

The experiences of one of the most successful Balinese companies in the import-export sector, Gabungan Impor dan Expor Bali (GIEB), are illustrative of the state's role in nurturing Bali's "national" capitalists during this period. ${ }^{53}$ GIEB was founded in December 1948, with the full assistance of the Dutch-sponsored governments of Bali and the Negara Indonesia Timur (NIT). In the words of a former Dutch official involved in the early stages of its formation, the company was established in order to help the tiny nascent Balinese bour-

45 For more details on the emergence of the local capitalist class, see Sarimin Reksodihardjo, Memorie Penjerahan, pp. 109-25.

46 Geertz, Peddlers and Princes, pp. 25-26. Geertz refers to Tabanan's post-independence businessmen as "... a relatively small group of displaced and threatened traditional rulers." Ibid., p. 120.

47 Ibid. pp. 106-20, 132.

48 Ibid, p. 132.

49 Ibid., pp. 26-27, 105-41.

50 Indeed, as Geertz acknowledges in a footnote, "... the nobility still dominates the civil service almost everywhere else in Bali. Even in Tabanan they have not been wholly displaced ... and their economic efforts are in part supplementary to a continuing governmental role rather than entirely replacing political activity." Ibid, p. 132.

51 lbid.

52 Grader wrote in 1950 that ". . the rise of Indonesian commerce in Bali during this period was in large part thanks to the enthusiasm and perseverance of a certain group of young men who emerged during the course of the revolution. ..." In "GIEB-III," Collectie Korn, OR 435-23, KITLV.

53 Apart from GIEB, the more prominent Balinese export-import companies included "Bali Baru" and the "Madjopahit Trading Co." 
geoisie "break the Chinese monopoly on trade." 54 The founder of GIEB was I Ketut Bagiada, until 1948 a high-ranking employee in the Department of Economic Development in Bali. The company's initial working capital of Rp. 100,000 increased to Rp. 2,000,000 by mid-1950, and it continued to prosper through the 1950s, with the assistance of the "nationalist" local state and the PNI in Bali. In fact, by 1956, GIEB had secured a monopoly position in the import sector by government order. All local distributors of major commodity imports (petrol, cloth, sugar, etc.) at that time were supplied by GIEB. ${ }^{55}$

Links with the local state also allowed many pemuda to move easily into the role of businessman-politician in the early 1950s. A case in point was the former pemuda, Dewa Made Dhana, who owned roughly 50 hectares of coffee land near Pupuan, in the highlands of west Buleleng. Shortly after independence, he established a coffee-exporting "cooperative," and became a leading figure in the coffee-growing and exporting business community. ${ }^{56}$ At the same time, he continued to be politically active in the PNI and served as vice-head of the Buleleng legislature (DPRD-Buleleng) from 1961 to 1966.57 According to Dewa Made Dhana himself, his personal friendship with the Bupati of Buleleng, his status as an ex-pemuda, and his close ties with officials at the Bank Rakyat ensured that he had no difficulty obtaining licenses, permits, and capital. Dewa Made Dhana's case was not exceptional. Two former leaders of Bali's Dewan Perjuangan Republik Indonesia (DPRI) were among a number of expemuda who established successful trading companies and cooperatives after independence. ${ }^{58}$ And as Bali's Republicans gained control of some key local government offices through the 1950s, pemuda access to state resources (including licenses and capital) continued to improve. In many cases, the local political and economic elite were the same people, or at any rate so closely linked by birth or friendship as to make no difference.

The close ties between the local state and Bali's new capitalist class had some important political implications. The interpenetration of political and economic elites meant that for much of this period the local state was strongly influenced by the interests of this new element of the middle class, represented principally by the PNI and in some areas by the PSI. This appears to have contributed to dissatisfaction and resentment among less advantaged groups, including urban laborers and peasants, and eventually to a political backlash in the form of support for the PKI and other parties of the left. ${ }^{59}$ As the dominance of the PNI and the PSI within the local state apparatus began to be challenged by Governor Sutedja and the parties of the left in the early 1960s, however, the position of capitalists associated with the

54 The official quoted is P.L. Dronkers, who had worked as a Controleur in Bali since 1946, and in 1949 was serving as Dutch advisor on economic affairs in Bali. Personal communication from P.L. Dronkers, February 9, 1988 and interview with Dronkers, Eindhoven, June 19, 1988.

55 See Sarimin Reksodihardjo, Memorie Penjerahan, p. 123. On the origins of GIEB, see Ch. J. Grader, "Gabungan Impor dan Expor Bali," in Collectie Kom, OR 435-23, KITLV.

56 Among other positions, he was head of the Pusat Koperasi Kopi Bali. See Komang Tjawi, Laporan Kopi di Pulau Bali 1958 (Singaraja: Kantor Tjabang Inspeksi Koperasi Daswati II Buleleng, 1958). He would appear to have benefited from an August 1950 law which required non-Balinese (i.e., Chinese) coffee exporters to pay a tax of Rp. 7.50 for each $100 \mathrm{~kg}$ of Arabica Coffee exported.

57 Interview with Dewa Made Dhana (former vice-head DPRD-Buleleng, 1961-1966), Singaraja, October 10, 1986.

58 Interviews with former pemuda leaders at Sanur (April 3, 1986) and Singaraja, September 28, 29, 1986.

${ }^{59}$ Commenting on the political implications of the emergence of a high caste capitalist class in Tabanan in the late 1950s, Geertz writes: "Many of the more articulate and educated commoners do regard [it] ... as a genuinely ominous and discouraging occurrence and as a betrayal of the promises of the Revolution.... it is upon such resentment that communism, just beginning to appear in Bali, feeds. ..." Geertz, Peddlers and Princes, p. 133. 
PNI and the PSI was increasingly threatened. This situation contributed to the dynamic of political conflict leading up to and after the October 1965 coup.

\section{Patronage and Political Conflict}

Dependence on the local state and party structures made Bali's new capitalists strong defenders of the principle of state intervention. Yet, despite this common interest, Bali's capitalists were not united politically. Within the small Balinese capitalist class there was a constant jockeying for local state patronage, and this rivalry inevitably resulted in a system of pay-offs to key state officials, and to accusations of favoritism and corruption. Moreover, because of their diverse political backgrounds-some had worked with the colonial state, some had been revolutionaries, and some were displaced aristocrats-and because political control of the local state, whose patronage they sought, remained fluid through most of the period 1950-1965, Bali's capitalists became involved with different political parties. In the immediate post-independence period, the majority of Bali's emerging capitalists were affiliated with the PNI which, particularly in the early years of the decade (1952-1955), dominated the key economic branches of the national and local bureaucracy. In later years, however, there were also "national" capitalists with links to the PSI and, still later, to the PKI and Partindo. ${ }^{60}$ Through their ties to the local state and political party structures, the "national" capitalists affiliated with each of the major parties were able - with varying degrees of success-to secure subsidies, licenses, and contracts from the local state.

The competition for contracts, licenses, and other favors, therefore, also took on a political dimension. The wealth and social prominence of some of Bali's new capitalists, and their influence within the political parties, meant that their personal views and interests were of much broader political import than might otherwise have been the case. Those who felt excluded from the state's economic patronage, for example, or who felt that their access was threatened by others, often construed their concerns in political language. This was evident in the late 1950s and early 1960s when Balinese capitalists affiliated with the PNI joined eagerly in the national policy to expel Chinese from Indonesia, a policy resisted by Sutedja and the PKI. Later, they seized the opportunity provided by the 1965 coup to remove competitors and to establish a dominant position within the local economy.

The strongly interventionist economic policies pursued nationally and locally, and the regulatory structures which these entailed, created an environment conducive to political manipulation and corruption. The procedure for granting export licenses in Bali, for example, entailed a high degree of state control and provided ample opportunity for pay-offs and political favors. Prospective exporters were required to undergo a "screening" process twice every year by a local government Coordinating Body until 1961; thereafter, screening was done once a year. According to an official government publication:

Before being designated as a bona fide exporter ... every business must make an official request to the local (Daerah) government, which includes all of the required letters and documentation. ... After hearing the considerations and opinions of the Coordinating Body, as well as the views of the Heads of those Departments which have some concern with export matters or the products being exported, the Daerah government issues a

\footnotetext{
60 Partindo, a left-nationalist party was formed nationally in 1958 by a PNI splinter group, opposed to the conservative PNI leadership under Suwirjo. Ideologically much closer to the PKI, it was highly critical of PNI foot dragging on land reform in later years. The Bali branch of Partindo was set up in 1961. In the local politics of late Guided Democracy, the PKI and Partindo were virtually indistinguishable. Both pushed hard for the "Nasakomization" of Bali's political institutions and for the implementation of land reform; and both suffered for their alleged complicity in the 1965 coup (G-30-S).
} 
decision regarding: aa / the acceptance or rejection of the new requests for an export license, and $\mathrm{bb} /$ the extension or cancellation of the licenses of existing exporters. ${ }^{61}$

The opportunities for graft and political favoritism were further enhanced by the system of export quotas. Cattle exporters, for example, were grouped into one of five quota categories, by executive government decision. Those in the lowest category were permitted to export only two head of cattle per month, while those in the highest could export as many as fifty. Similar opportunities were available in the construction sector, as public works projectsbridges, roads, schools, hotels, etc-constituted the largest single local state expenditure, after public sector wages, in every budget between 1951 and 1965.

The imposition of martial law in 1957 altered the channels if not the basic mechanisms of state patronage. Under martial law, the Regional War Administrator (Peperda), Lt. Col. Minggu, became the central economic decision-making authority. In 1959 alone, he issued dozens of executive orders pertaining to every aspect of economic life: licensing of businesses, contracts, prices, wage scales, directorships. ${ }^{62}$ In the same year, the Bali Regional Trading Pool (Pool Perdagangan Daerah Bali), headed by Major Iwan Stambul (Commander [Panglima] of KODAM [Regional Military Command] XVI Sector-1/Bali) was set up and became the omnipotent clearing house for economic affairs in Bali. ${ }^{63}$ Each new rule provided an additional potential source of illegal revenue for those charged with enforcing it. At the same time, the position of Bali's "national" capitalists came increasingly to depend on the local military apparatus.

For a few years, then, military authorities, rather than the civilian bureaucracy or the political parties, became the main channel for state patronage. However, the position of the military in Bali differed in one important respect from that of the military in Java. Whereas in Java it had gained control of large tracts of land, with the nationalization of foreign plantations, in Bali there were practically no foreign plantations. In 1950, for example, there were only two foreign-owned coffee plantations in Bali/Lombok; together they covered a mere 74 hectares and produced only 28 tons of coffee. In East Java, by contrast, there were in the same year, 101 Dutch-owned coffee plantations, covering 27,058 hectares and producing 9,698 tons of coffee per year. ${ }^{64}$ Thus, while the military played a central role as dispenser of state patronage in Bali, it did not quickly amass landed wealth like the military units in Java. This meant that there was less immediate economic reason for local military hostility to the land reform and to leftist mobilization in the countryside. Because their economic interests were based on control of the systems of trade and distribution, the military in Bali was ultimately much more concerned with maintaining its position of power within the state apparatus. It could afford to cooperate with virtually any political party or grouping, left or right, as long as that position was not fundamentally challenged. The absence of landed wealth, however, meant that the economic base of the military in Bali was ultimately much more vulnerable to political change.

${ }^{61}$ Monografi Daswati I Bali, pp. 109-10.

62 The official orders and decisions of Lt. Col. Minggu are compiled in Angkatan Darat Republik Indonesia, Himpunan Keputusan, Perintah, Instruksi, Penetapan, Peraturan, Pengumuman Dari Penguasa Perang Daerah Untuk Daerah Tk I Bali/Nusra Barat/Nusra Timur, Tahun 1959 ([Denpasar]: KODAM XVI Nusa Tenggara, 1959).

63 The structure and functions of this regulatory agency are outlined in the publication Pool Perdagangan Daerah Bali (Singaraja: n.p., 1959).

64 In total (excluding small-holder production), Indonesia produced 11,078 tons of coffee in 1950, on plantations covering 45,065 ha. Almanak Pertanian 1953 (Jakarta: Departemen Pertanian, 1953), p. 359. 
In mid-1959, Lt. Col. Minggu was dismissed as Pangdam XVI/Udayana, according to rumors, a victim of General Nasution's anti-corruption drive within the military. His successor, Supardi, made extensive organizational changes in the Regional Military Command (KODAM), but in 1961 Sukarno decided to bestow the powerful post of Pepelrada (Regional Leader for the Implementation of Dwikora ${ }^{65}$ ) on Governor Sutedja rather than on the military commander. Stripped of its role as supreme state economic authority, the military in Bali ceased to have an autonomous economic base, and thus became substantially less independent politically than the military authorities in Java. In the short term, this loss appears to have encouraged military cooperation with Sutedja. However, such a pragmatic alliance did not preclude a military move against the governor when he became politically vulnerable after the October 1965 coup.

As governor and Pepelrada, Sutedja was in a position to manage the flow of economic patronage from 1961 to 1965 . As political relations between the parties grew increasingly antagonistic, there were charges that he was dispensing favors to political allies in the PKI and Partindo. The most notorious case of alleged patronage involved the lucrative contracts for the construction and staffing of the Bali Beach Hotel. The brainchild of President Sukarno, the Bali Beach was the first luxury-style hotel on the island. ${ }^{66}$ Although it is difficult to assess the verity of the charges, in 1965 PNI-affiliated organizations and businessmen claimed that Sutedja had granted the contracts-those for staff training and management as well as the actual construction of roads and the multi-story hotel-to PKI/Partindo-affiliated companies, unions, and individuals. And in the aftermath of the October coup, there were persistent calls for the "retooling" and "freezing" of Bali Beach Hotel contractors, managers, and training staff. ${ }^{67}$ To what extent this was merely sour grapes on the part of individuals who were denied lucrative contracts is difficult to determine. But it was indicative of the way in which the economic interests of Bali's capitalists influenced and found expression in anti-PKI political campaigns of the post-coup period.

In spite of the allegations against him, it is not at all clear that Sutedja's decisions on economic policy always followed party lines. It is known, for example, that he had close contact with at least one prominent PNI businessman, who reportedly felt so greatly indebted to Sutedja that he intervened to prevent his murder at the hands of the PNI in late 1965. ${ }^{68}$ What does seem clear is that, in a place as small, socially and politically, as Bali, with a minuscule and overlapping economic and political elite, personal favors, corruption, and pay-offs were an unavoidable part of the system. Bali's new capitalists, whatever their nominal political orientation, remained dependent upon state and party patronage, and

\footnotetext{
65 Dwikora = Dwikomando rakyat- "the people's two mandates" to crush Malaysia and defend the Revolution.

${ }^{66}$ Control of the tourist industry was hotly contested at this time. In September 1960, the locally controlled tourism coordinating body, "Bali Tour," had been taken over, against strong objections, by the centrally directed NITOUR. This was not a power struggle between center and region, as it was sometimes portrayed, but rather between competing Balinese capitalists. "Central" control in effect meant control by the local group with the best connections to Governor Sutedja and his allies. The manager of NITOUR-Bali was the Partindo member and Sutedja associate, I.B.K., and the locally generated NITOUR profits were to be divided between the provincial government ( 60 percent) and the National NITOUR office. See "Status NITOUR Bali Office Ditanjakan," Suara Indonesia (Denpasar), September 5, 1964.

${ }^{67}$ See, for example "Bersihkan Bali Beach Hotel Dari Unsur G-30-S," Suara Indonesia (Denpasar), November 11, 1965.

68 Sutedja's fate after the October coup remains something of a mystery. He was called to Jakarta by Sukarno on November 11 and apparently never returned to Bali, but it is unclear whether he was killed, as some PNI-Bali officials claimed at the time. For further discussion of Sutedja's role in the aftermath of the coup, see my "Politics of Violence in Modern Bali," ch. 12.
} 
were therefore prepared to work within virtually any state system. It is not surprising, therefore, that a number of wealthy businessmen became affiliated with the PKI and Partindo in the final years of the Old Order.$^{69}$ When it became clear that Sutedja had lost control of the state apparatus which effectively determined their livelihood as a class, these businessmen did not find much difficulty in shifting allegiance to the PNI, and disavowing any previous connection with the PKI or Partindo. Moreover, they took advantage of the purge-politics after the October coup, to attack both their Chinese and other Balinese competitors.

\section{Land Reform and Rural Relations of Production}

Access to agricultural land was one of the burning political issues of the years 1950 to 1965. As the sense of economic crisis grew through the early 1960s, and as inflation accelerated, land, already scarce and always an object of dispute, became virtually the only guarantee of livelihood. Unlike the Konfrontasi campaign against Malaysia, or the struggle for West Irian, land reform had an unmistakable significance for virtually every Balinese; most stood clearly to gain or to lose in the event of a straightforward interpretation of the laws.

Land reform lay at the core of the sudden expansion of the PKI and the BTI in Bali in the early 1960s, and triggered a significant realignment of political forces along class lines. Whereas the revolutionary movement (1945-1949) had been based on a coalition of various classes, and had in some cases relied on the resources and autonomy of the more prosperous elements within the coalition, the politics of land and land reform encouraged a pattern of division based more clearly on class. ${ }^{70}$ As land reform and other economic issues came to dominate the political agenda both at the national level and in Bali, the social bases of the two major political parties (PKI and PNI) came to reflect more distinct class positions. Even former Republicans and ex-pemuda, once more or less united by their common struggle, increasingly found themselves in opposite camps.

Access to land was already a contentious issue in the early 1950s because at least 3,000 Balinese pemuda had (in 1950) suddenly been returned to "society."71 In the course of the Revolution, the families of many pemuda had been forced to sell or pawn their land, and still others had lost legal title to their holdings as a consequence of their "illegal" guerrilla activity. Those who had taken over these holdings during the Revolution with the blessing of the village assembly, or of local officials, were not inclined now to return them to their original owners or renters. Together with a general antipathy towards things "feudal," these developments pushed land reform to the center of the pemuda political agenda.

\footnotetext{
69 One of the wealthiest businessmen with links to the PKI was L.T., who, according to Soe Hok Gie, "financed the PKI in Bali." There is a report from October 1965, of L.T. donating an entire school building to the government of Buleleng. In the aftermath of the coup, he appears to have escaped unscathed by virtue of his friendship with an influential PNI leader and ex-pemuda. How far back this association goes is hard to determine, but it is quite likely that it dates from the Revolutionary period. At that time, it was said that the pemuda received substantial financial support from a local Chinese businessman.

${ }^{70}$ For a full discussion of the social and class bases of the National Revolution in Bali, see my "State, Society and Political Conflict in Bali, 1945-1946," Indonesia 48 (April 1988), and my dissertation "The Politics of Violence in Modern Bali" ch.7.

71 The figure of 3,000 comes from $\operatorname{Sin} P_{0}$, October $25,1950$.
} 
One of the first acts of Bali's legislature (DPRD) was the establishment, in March 1951, of a legal minimum harvest share of 50 percent for tenants. ${ }^{72}$ The legislation also forbade "melaisin" and other systems of pre-payment in cash for the right to farm a tract of land, and placed limits on the right of landlords to evict tenants without due notice or sufficient cause. The new government in Bali also made changes to the system of taxation. Perhaps the most important was the land tax exemption, noted earlier, granted to those with holdings smaller than 3 hectares, which effectively freed more than 80 percent of land-owners from taxation. 73

While on paper these were encouraging signs for the anti-feudal pemuda and for the vast majority of peasants, it soon became clear that the local legislation on landlord-tenant relations was essentially unenforceable. Tenants, especially in the worst areas, were unwilling to risk alienating a landlord who happened also to be an important local patron. Moreover, in many areas traditional bonds of loyalty to members of the local puri and other aristocratic families inhibited tenants from seeking a strict enforcement of the law. Most still tended to accept the terms set by the landlord. In the early 1950s, moreover, peasant organizations were at their weakest, and Republican state capacity was at its least effective, in precisely those areas-primarily the four eastern kingdoms-where the terms of tenancy were most unfair. Though the local state was in a good position to enact progressive legislation, it was more-or-less incapable of enforcing it. ${ }^{74}$

The National Land-Reform Legislation

The national land-reform legislation of the early 1960s-which mandated the redistribution of agricultural land and changes in the terms of harvest-sharing arrangements-differed substantially from the local agrarian legislation of the 1950s in its political implications in Bali. ${ }^{75}$ The changed economic and political environment in Bali in which the national legislation was introduced, made it far more contentious and more volatile politically. Initiated by the PNI and Sukarno, and later supported by the PKI, the objective of the laws appears to have been at least as much to stimulate an increase in agricultural production by small independent producers, as to guarantee equitable relations of production in the countryside. Yet whatever their original objective, the laws held a strong appeal for marginal tenant farmers and agricultural laborers, particularly at a time of rampant inflation. The law on land redistribution allowed a maximum land holding of 5 hectares per family on wet-rice land (sawah) in the most densely populated areas, with greater holdings allowed for sawah and drylands in less densely populated regions (See Table 3). ${ }^{76}$ Holdings in excess of these

\footnotetext{
72 This was the "Peraturan Penjakap Daerah Bali tgl 30 Maret 1951, No. 5/DPRD." Subsequent local land-reform regulations included the "Peraturan Penjakap Penguasa Perang Daerah Nusa Tenggara, tgl. 17 April, 1958, No. P.R.T.R. W/009/P.P.D./1958."

73 Other changes in the tax system included the abolition of the Road Tax and the "Peralihan" (transfer) tax, and their replacement with an income tax.

74 See Ida Bagus Gde Putra, "Pelaksanaan Landreform dan Keresahan Masyarakat di Kabupaten Karangasem (1960-1965)," Thesis Universitas Udayana, Denpasar, 1986.

75 The land-reform legislation was a composite of several basic laws and dozens of regulations, covering various aspects of land rights. The basic laws were: Undang-Undang No. 5 Tahun 1960 Tentang Peraturan Dasar Pokok-Pokok Agraria (September 24, 1960); Undang-Undang No. 56 PRP Tahun 1960 Tentang Penetapan Luas Tanah Pertanian (December 29, 1960); Undang-Undang No. 2 Tahun 1960 Tentang Perjanjian Bagi-Hasil (Tanah Pertanian) (January 7, 1960); and Peraturan Pemerintah No. 224 Tahun 1961 Tentang Pelaksanaan Pembagian Tanah dan Pemberian Ganti Rugi. Most of the laws and regulations can be found in UUPA dan Landreform; Beberapa Undang Dan Peraturan Hukum Tanah (Surabaya:Karya Bhakti, 1984).

76 The maximum holdings were set out in Article 1(2) of Undang-Undang No.56 PRP Tahun 1960 Tentang Penetapan Luas Tanah Pertanian (December 29, 1960).
} 
limits were to be redistributed by the state, with priority given to those actually cultivating the plot in question. A separate regulation outlawed ownership of land by absentee landlords, and provided for redistribution of such holdings by the state. ${ }^{77}$ Where land holding was not heavily concentrated, these regulations directly affected a relatively small percentage of rural landowners, while effectively exempting many whose extensive holdings were distributed in small packages amongst relatives and clients. Nevertheless, because so many rural households owned little or no land, the new laws created at least the potential for significant gains by a very large number of people. Optimism was fueled by the establishment in the land-reform laws of an ideal minimum holding of 2 hectares per household.

Table 3. Maximum Landholdings By Population Density on Sawah and Drylands According to Law No. 56 of 1960

\begin{tabular}{ccc}
\hline \hline Population Density & $\begin{array}{c}\text { Maximum Holdings } \\
\text { on Sawah }\end{array}$ & $\begin{array}{c}\text { Maximum Holdings } \\
\text { on Drylands }\end{array}$ \\
\hline $\begin{array}{c}\text { Sparse } \\
\left.\text { (Fewer than } 50 \text { persons } / \mathrm{km}^{2}\right)\end{array}$ & 15 hectares & 20 hectares \\
$\begin{array}{c}\text { Not Very Dense } \\
\left(51-250 \text { persons } / \mathrm{km}^{2}\right)\end{array}$ & 10 hectares & 12 hectares \\
$\begin{array}{c}\text { Quite Dense } \\
\left(251-400 \text { persons } / \mathrm{km}^{2}\right)\end{array}$ & 7.5 hectares & 9 hectares \\
$\begin{array}{c}\text { Very Dense } \\
\left.\text { (More than } 400 \text { persons } / \mathrm{km}^{2}\right)\end{array}$ & 5 hectares & 6 hectares \\
\hline
\end{tabular}

Source: Article 1(2), Undang-Undang No. 56 PRP Tahun 1960 Tentang Penetapan Luas Tanah Pertanian.

Even more dramatic in its implications was the law on harvest sharing. ${ }^{78}$ The law acknowledged that local conditions would have to be taken into account in determining the precise division of the harvest between tenant and landowner, but it established as an ideal a division of $1 / 2$ to the tenant, and $1 / 2$ to the owner on sawah and a $2 / 3: 1 / 3$ division on drylands. It also required certain production costs to be borne by the landowner. The terms of the harvest-sharing law were less radical than those earlier proposed by the PKI and BTI and demanded again by some of their members after $1963 .{ }^{79}$ Nevertheless, even as it stood, the law promised a significant change from the practice in many parts of Java and Bali, where the customary division of the harvest was heavily balanced in favor of the landowner. Moreover, because it left the final determination of the harvest share in each area to the Bupati, the law opened opportunities for significant political conflict at the local level.

77 The regulation governing the redistribution of the holdings of absentee landlords was Peraturan Pemerintah No.224 Tahun 1961 Tentang Pelaksanaan Pembagian Tanah dan Pemberian Ganti Rugi.

78 The basic law was Undang-Undang No.2 Tahun 1960 Tentang Perjanjian Bagi-Hasil (Tanah Pertanian) (January 7, 1960). The ideal division of harvest arrangements were outlined in a clarification of Article 7 of the law.

79 The PKI had earlier proposed a division of $6 / 10$ to the tiller of the land, 2/10 to the owner and $2 / 10$ to the state. Ina Slamet, "Views and Strategies of the Indonesian Peasant Movement," p. 10. In parts of Bali, after 1963, the PKI and BTI demanded a 2/3:1/3 division in favor of the tenant on sawah. 
The PKI decision in 1963 to pursue the implementation of land reform through an aggressive rural mobilization campaign marked an important departure from the party's united front strategy. ${ }^{80}$ The decision was made, at least in part, to increase the political leverage of the party at the center. It also apparently emerged out of an awareness that the party needed to do more than it had until then to defend the interests of workers and peasants at a time of economic crisis. Once set in motion, however, the land-reform campaign appears to have taken on its own momentum, and local PKI and BTI cadres began to make demands which exceeded the relatively modest changes stipulated in the laws. In some areas local activists also went beyond what was considered desirable by the party leadership in Jakarta. ${ }^{81}$ Unilateral seizures of land by BTI peasants, known as aksi sepihak, were a case in point. Originally supported by the PKI leadership and by President Sukarno as a legitimate means to ensure the implementation of the land reform, the aksi sepihak were officially disavowed by Sukarno and the national leadership of the PNI and the PKI, in a joint statement issued in December $1964 .{ }^{82}$ Nevertheless, the unilateral actions, and acts of intimidation and violence by both PKI and PNI supporters, continued into 1965.83 Indeed, PKI cadres conducting research in a number of villages in Java, Bali, and Sumatra in early 1965 judged some BTI members to be:

... too leftist, ready to throw themselves on the devils, longing for a quick reversal of the situation and not believing in any peaceful means to break the power of the multi-faced devils who control[ed] their lives. ${ }^{84}$

The aggressiveness of the PKI and BTI in pushing the implementation of the land reform after 1963 had an understandable appeal to landless laborers and poor tenant farmers, and contributed to the increasing popularity of both organizations after 1963. This was particularly true in the plantation sector, but it was also evident where average landholdings were small and where the terms of tenancy were skewed against tenants. Peasant militancy-as evidenced in the aksi sepihak - constituted a real threat to landowners and to the military who, after the imposition of Martial Law in 1957, had come to have a strong stake in the economic status quo. Indeed, the land-reform issue became a major focus of political struggle in rural areas of Java and Bali between 1963 and 1965 and helped to accelerate the process of polarization on class lines. It was, in part, in retaliation against the successes of the left during this time, that the military and its conservative rural allies struck back with such violence at the PKI and BTI after the 1965 coup.

\footnotetext{
${ }^{80}$ Mortimer writes that, by late 1963 , the PKI "... judged the time ripe for a class offensive in the villages, the first decisive turn to a struggle hinged on class cleavages." in Mortimer, "Class, Social Cleavage, and Indonesian Communism," p. 18. For a description of the PKl's strategy and an analysis of the historical and political considerations which shaped it, see ibid., pp. 8-12. Ina Slamet describes the PKI decision as part of a plan to "... initiate a real class struggle aiming at a more basic transformation of agrarian relations." See Slamet, "Views and Strategies of the Indonesian Peasant Movement," p. 18.

81 Benjamin White writes that, on the question of land reform, the BTI was more militant than the PKI leadership which "... often showed an ambivalent attitude towards these more radical campaigns." White, "Rural Resistance," p. 10.

82 The statement, issued on December 12, 1964, was known as the Bogor Declaration. Mortimer argues that the PKI was relieved to see a compromise on the issue, because the aksi sepihak campaign had ceased to have any positive benefit for the party at the national level. Mortimer, "Class, Social Cleavage, and Indonesian Communism," pp. 19-20.

${ }^{83}$ The BTI, which emerged during the Revolution, had not always been associated with the PKI. An institutional and ideological basis therefore existed for the BTI to take an independent position from the national PKI leadership, particularly on the issue of land reform.

84 Slamet, "Views and Strategies of the Indonesian Peasant Movement," p. 34.
} 


\section{Relations of Production in the Balinese Countryside}

By 1950 , roughly 85 percent of all agricultural land in Bali was privately owned, but the average size of landholdings was small, and declining in the face of rapid population growth. ${ }^{85}$

Table 4. Land Holdings by Size in Bali, 1963

\begin{tabular}{lcccc}
\hline \hline Kabupaten & $\begin{array}{c}\text { \% Holdings } \\
<0.5 \text { ha. }\end{array}$ & $\begin{array}{c}\% \text { Holdings } \\
>2.0 \text { ha. }\end{array}$ & $\begin{array}{c}\text { Average Farm } \\
\text { Size (ha.) }\end{array}$ & $\begin{array}{c}\text { Total Agric. } \\
\text { Land (ha.) }\end{array}$ \\
\hline Badung & $62 \%$ & $5 \%$ & .73 ha. & 37,908 \\
Bangli & $43 \%$ & $19 \%$ & 1.25 ha. & 19,251 \\
Buleleng & $44 \%$ & $17 \%$ & 1.38 ha. & 35,140 \\
Jembrana & $22 \%$ & $36 \%$ & 1.48 ha. & 13,926 \\
Gianyar & $70 \%$ & $3 \%$ & .56 ha. & 37,380 \\
Karangasem & $68 \%$ & $3 \%$ & .55 ha. & 27,180 \\
Klungkung & $66 \%$ & $4 \%$ & .78 ha. & 17,358 \\
Tabanan & $44 \%$ & $15 \%$ & 1.13 ha. & 46,530 \\
TOTALS & $54 \%$ & $11 \%$ & .95 ha. & 234,674 \\
Java/Madura & $52 \%$ & $6 \%$ & - & - \\
\hline
\end{tabular}

Source: Propinsi Bali, Kantor Sensus dan Statistik, Himpunan Hasil2 Sensus Dan Survey 19611967, Singaraja, 1968.

Fully 89 percent of all holdings in Bali were smaller than 2 hectares, and more than half were smaller than 0.5 hectares, a greater proportion than in Java-Madura (See Table 4). In some areas, the proportion of holdings smaller than half a hectare was between 60 and 70 percent. The eruption of Gunung Agung in 1963, which destroyed tens of thousands of hectares of productive land, made the shortage of land even more acute in the final years of the Old Order. One can see here the basis for a very substantial degree of support for a policy of land reform which proposed a minimum of 2 hectares of sawah for each farm household.

While this minimum target was clearly impossible to achieve in Bali-because there simply was not enough land to go around-the prospect of getting any amount of land was met with great enthusiasm. Moreover, because the average size of landholdings in Bali was so small, more stood to gain than to lose. This was central to the success of the PKI and the BTI in Bali. ${ }^{86}$ Though the continued dependence-and still powerful bonds of loyalty-of tenants on their landlords discouraged some from taking action, the issue of land reform

85 According to the 1963 agricultural census the average farm size in Bali was 95 hectare, and in some areas, such as Gianyar, Karangasem, Klungkung, and Badung, it was significantly smaller. These figures must be treated with caution, however, because they show an average size of landholding larger than the average recorded some twenty-five years earlier. In 1938, for example, the average size of landholding in Tabanan was, for sawah, $0.61 \mathrm{ha}$. and for dry land, $1.08 \mathrm{ha}$. Overall, this meant an average size of landholding of $0.86 \mathrm{ha} . / \mathrm{per}$ person, while in 1963, the average farm size in Tabanan was said to be 1.13 ha. The 1963 figures, therefore, probably overestimate the actual size of landholdings in Bali. See H.J. Hoekstra, "Nota van Toelichtingen betreffende het in te stellen Zelfbesturende Landschap Tabanan" (Regeerings Commissaris voor de Bestuurshervorming in de Groote Oost, typescript, 1938).

86 Interviews with: I Gusti Putu Yasa Arimbawa (former head of Petani, Tabanan), December 20, 1986; Ida Bagus Indra (former Punggawa Sawan, 1955-1960; Tejakula, 1961-1965; Kubutambahan, 1966/67), December 17, 1986. 
brought class differences into sharper focus, and encouraged a certain migration across party lines.

Table 5. Land Redistribution in Tabanan, Karangasem, Gianyar, and Badung, 1964

\begin{tabular}{lcccc}
\hline Kabupaten & $\begin{array}{c}\text { Total Area (ha.) to } \\
\text { be Redistributed }\end{array}$ & $\begin{array}{c}\text { Area (ha.) not yet } \\
\text { Redistributed } \\
\text { and (\%) }\end{array}$ & $\begin{array}{c}\text { Owners } \\
\text { Affected }\end{array}$ & $\begin{array}{c}\text { Average Holding } \\
\text { (ha.) of Affected } \\
\text { Owners }\end{array}$ \\
\hline Tabanan & 2,257 ha. & $1,664(74 \%)$ & 849 & 2.65 ha. \\
Karangasem & 1,629 ha. & $351(21 \%)$ & 127 & $10.07 \mathrm{ha}$. \\
Gianyar & $1,525 \mathrm{ha}$. & $1,082(71 \%)$ & 144 & 10.59 ha. \\
Badung & $1,153 \mathrm{ha}$. & $400(35 \%)$ & 383 & $3.01 \mathrm{ha}$. \\
Total/Average & 6,564 ha. & $3,497(53 \%)$ & 1,503 & $4.36 \mathrm{ha}$. \\
\hline
\end{tabular}

Sources: Suara Indonesia (Denpasar), May 17, 1964; Putra, "Pelaksanaan Landreform," pp. 81, 87.

Though there were a number of large landlords in Bali, landed wealth was generally speaking not heavily concentrated. Holdings of more than 2 hectares comprised only 11 percent of the total agricultural land in 1963. The number whose holdings exceeded the legal limit of 5 hectares of sawah and 6 hectares of dryland was even smaller. ${ }^{87}$ This meant that a surprisingly small number of landlords were actually in any immediate danger of losing part of their land under the terms of the land-reform laws. Table 5 indicates that in four kabupaten-Tabanan, Badung, Karangasem, and Gianyar-the total number of owners potentially affected was only about 1,500 . Yet, while the number of owners was relatively small in these areas, and throughout the island, their social and political influence was not. The landowners included members of leading puri and other households which remained socially and politically influential in their respective communities. Indeed, according to figures compiled by the Office of the Land Tax in 1949 (See Table 6), among the largest landowners in Bali were, in order of the size of their holdings, the former Rajas of Karangasem (672 ha.), Gianyar (304 ha.), Bangli (240 ha.), Buleleng (156 ha.), and Badung (144 ha.). 88 In the cases of Badung and Buleleng, the figures represent the total holdings of the whole family. But in the others, they represent only that portion of the royal family's landed assets that were held by the Raja himself. Thus, for example, an uncle of the former Raja of Karangasem also had extensive landholdings-92 ha. of sawah and $317 \mathrm{ha}$. of dryland-so that together, the two members of the family owned about 5 percent of the sawah in Karangasem. As leading local patrons, these men maintained a substantial degree of influence over the political choices and economic opportunities of other members of the community.

${ }^{87}$ In accordance with the regulations linking the legal limits to population density, the maximum size of landholdings permitted were even higher in much of Bali. In Karangasem, for example, where the population density was judged to be "quite dense," the limits were 7.5 hectares of sawah and 9 hectares of dryland (See Table 3).

88 These figures were compiled by the Head of the Bali Land Tax Office, in April 1949, and supplied to George McT. Kahin that same month. It must be said that there is considerable uncertainty about the precise size of the landholdings of the Dewa Agung of Klungkung. The 1949 figures indicate that they were rather meager, totaling less than 10 hectares (See Table 6). On the other hand, some Dutch sources indicate that they were considerable. Interview with Prof. J. van Baal (former Assistant Resident, Bali [1946/47]), May 9, 1987. One of the main reasons for thinking that the Dewa Agung's holdings were substantial is that the royal lands in Klungkung were apparently not confiscated by the Dutch at the beginning of the century. During the land reform of 1963-1965, moreover, the Dewa Agung was said to have been one of the major landowners, but land-reform officials would not dare to redistribute his land. Interview with an official at the Kantor Agraria, Bali, November 1986. 
Table 6. Officially Recorded Landholdings of the Former Rajas of Bali, 1949

\begin{tabular}{lccc}
\hline \hline Former Raja & Total Holdings (ha.) & Sawah (ha.) & Dryland (ha.) \\
\hline Buleleng & 156 & 78 & 78 \\
Jembrana & 11 & 3 & 8 \\
Tabanan & 9 & 2 & 7 \\
Badung & 144 & 34 & 110 \\
Gianyar & 304 & 202 & 102 \\
Klungkung & 9 & 3 & 6 \\
Karangasem & 672 & 303 & 369 \\
Bangli & 240 & 73 & 167 \\
\hline
\end{tabular}

Source: Bali Land Tax Office, April 1949.

Perhaps more far reaching in their impact than the redistribution of land, and equally contentious, were the laws which governed landlord-tenant relations. Available statistics indicate that 36 percent of farms in Bali were cultivated under some tenancy arrangement, or only slightly less than the figure for Central Java (See Table 7). ${ }^{89}$ Conditions of tenancy varied widely from region to region. By far the worst terms for the tenant were found in the eastern kingdoms of Karangasem, Klungkung, Gianyar, and Bangli, where tenants kept as little as one fifth $(1 / 5)$ of the harvest, and where they were often required to pay advances to the landlord in cash or kind, for the right to cultivate the land. ${ }^{90}$ A 1965 study of a village in west Gianyar, for example, recorded the following case:

... a sharecropper surrendered his son to the landlord to work for him for fear of being ousted from his land, and after he had to take back his son because he needed him too much himself, he replaced him with the boy's younger sister. . . ${ }^{91}$

In the central kingdoms of Badung, Tabanan, and Buleleng-the base areas of the Republican resistance during the Revolution-the conditions were somewhat better for the tenant, the crop generally being divided 50-50 between landowner and tenant. ${ }^{92}$ Yet while tenants in these central regions were relatively well off from the viewpoint of tenancy arrangements, it would be misleading to characterize them as a uniformly prosperous class. Important differences remained between the prosperous land-owning peasantry and those with little or no land, whose situation deteriorated with the worsening economic situation (especially the inflation) in the mid-1960s. Conditions were probably most disadvantageous

${ }^{89}$ In fact, these figures probably underrepresent the level of tenancy, because they indicate lower rates of tenancy than the figures from 1950. For example, the level of tenancy on sawah land in Tabanan in 1950, was 16 percent, while in 1963, roughly 90 percent of all agricultural land in Tabanan was said to be owner operated. I Gusti Gde Raka, Monografi Pulau Bali, p. 34; and Propinsi Bali, Kantor Sensus dan Statistik, Himpunan Hasil2 Sensus Dan Survey 1961-1967 Bali (Singaraja, 1968).

90 Raka, Monografi Pulau Bali, pp. 33-34. The terms of harvest sharing depended on several factors including the type of land (sawah or dryland) and the type of crop. Thus, in Karangasem for example, a tenant cultivating sawah would customarily receive $2 / 5$ of the crop, with $3 / 5$ going to the owner, while a tenant on dryland with coconut trees or some other long-term crop, would receive only 1/5 of the produce. Putra, "Pelaksanaan Landreform," p. 97.

91 Slamet, "Views and Strategies of the Indonesian Peasant Movement," p. 119.

92 Terms of tenancy varied locally, of course, and according to the kind of crop cultivated. The crop-sharing arrangements mentioned here refer specifically to the main rice crop (padi kertamasa) on irrigated fields. There were also variations in the respective burden of owner and tenant with regard to the provision of seed, and other inputs. 
for landless agricultural laborers, many of whom worked in the coffee-growing areas of Buleleng and Tabanan. In a coffee-growing village in Buleleng, for example, a 1965 report noted that:

Any sharecropper or annual laborer could be ousted at will if his performance or attitude... displeased his employers. The landlords would not shrink from destroying the laborers' crop or even razing their huts with the help of hired bandits. ${ }^{93}$

Table 7. Percentage of Farms Owner-operated and Tenanted in Bali, 1963

\begin{tabular}{lcc}
\hline \hline \multicolumn{1}{c}{ Kabupaten } & \% Fully Owned & \% Tenanted \\
\hline Badung & $43 \%$ & $57 \%$ \\
Bangli & $60 \%$ & $40 \%$ \\
Buleleng & $56 \%$ & $44 \%$ \\
Jembrana & $57 \%$ & $43 \%$ \\
Gianyar & $71 \%$ & $29 \%$ \\
Karangasem & $40 \%$ & $60 \%$ \\
Klungkung & $48 \%$ & $52 \%$ \\
Tabanan & $73 \%$ & $27 \%$ \\
Bali (average) & $64 \%$ & $36 \%$ \\
C. Java (average) & $62 \%$ & $38 \%$ \\
\hline
\end{tabular}

Source: Propinsi Bali, Kantor Sensus dan Statistik, Himpunan Hasil2 Sensus dan Survey 1961-1967 Bali, Singaraja

In short, rural relations of production in Bali were such that tenants and agricultural laborers stood to gain in at least two ways under the terms of the national land-reform legislation. First, they could hope for the enforcement of certain legal restrictions on the terms of tenancy, such as the distribution of the harvest, and of production costs. Second, though somewhat less likely, there was the possibility that they would receive a portion of the land they were actively farming which was deemed to exceed the maximum limits or to be owned by an absentee landowner. It remains to be seen to what extent and in what manner such economic considerations actually influenced political choice, mobilization, and conflict in Bali.

\section{Class, Culture, and Mass Politics}

In 1963 Clifford Geertz summarized the argument which would powerfully influence all subsequent analyses of Balinese politics under the Old Order. In Bali, he wrote

....political affiliation tends to follow traditional allegiances rather closely, so that rival kin-groups, villages and caste groups find themselves on opposite sides of the political fence as a mere reflex of their position in local social structure. As yet, the persistence of customary social forms remains strong enough to force national political processes to realize themselves in terms of properly Balinese concerns, and rather than shaping local loyalties ... they are able only to reflect them. [emphasis added] ${ }^{94}$

\footnotetext{
93 Slamet, "Views and Strategies of the Indonesian Peasant Movement," pp. 125-26.

94 Geertz, Peddlers and Princes, p. 22.
} 
In support of this claim he referred to a 1959 article by Hildred Geertz, in which she wrote that, in Bali "seemingly modern [political] competition is in actuality not one of ideologies but one of traditional factions, of ancient grudges and time honored alliances." 95

These were important observations which have helped to explain at least one of the ways in which political parties could rapidly develop mass political followings in Bali in the early 1950s. Unfortunately the Geertzian paradigm has also helped to sustain some very dubious bits of conventional wisdom about Balinese politics. One of the most tenacious of these is that all political parties relied principally on high-caste individuals with "traditional" constituencies to establish and broaden their mass bases. ${ }^{96}$ Carol Warren refers to this pattern of mobilization as a "vertical alliance" strategy-implying a political alliance which crossed or transcended class lines. ${ }^{97}$ There are essentially two arguments-or rather, bits of evidence-which have been advanced as proof that class was politically unimportant in Bali; both pertain specifically to the case of the PKI. ${ }^{98}$ It is worth looking critically at this evidence before proceeding further.

The first argument arises from the fact that the PKI in Bali had leaders and members of the three highest castes (triwangsa). This is taken as evidence that the PKI was not genuinely a party of workers and peasants. Triwangsa with PKI sympathies or leadership positions included, for example, Governor Sutedja (Satria), A.A.G.A. (Satria), A.A.A.D. (Satria), members of the Geria P. (Brahmana), and I.B.D. (Brahmana). The fact of a triwangsa presence within the PKI-Bali is beyond dispute, but if this is advanced as a claim about the party's class character, it is misleading. The categories of caste and class in Bali are not interchangeable; that is to say, the caste status of an individual is not a reliable guide to his or her economic, political, and ideological position.

Even if we were to accept the premise that a particular caste implies a particular classfor to some extent the two categories do overlap-there remains a serious problem with the argument. The presence of triwangsa within the PKI organization cannot, in fairness, be taken as an indication of the overall class character of the party and its social base. There is evidence, to be discussed below, that the PKI and BTI had begun to develop a strong mass base among the poorest farmers and town-dwellers, and that at the local level, party and mass organization cadres were not predominantly men and women of high caste. Even at the provincial level, some of the most influential PKI leaders and sympathizers were commoners, including, for example, the head of the PKI Provincial Committee, K.K., and the expemuda G.P., widely acknowledged to be Sutedja's right-hand man. It is not clear, then, why

95 Hildred Geertz, "The Balinese Village," in National and Local Loyalties in the Indonesian Village: A Symposium, ed. G. William Skinner (New Haven: Yale University Press, 1959). The Geertzes provide some-albeit rather cursory-evidence in support of this claim in their joint study, Kinship in Bali, which is based on fieldwork conducted in the late 1950s. Discussing the hamlet of Tihingan, they note that political party affiliation overlapped almost exactly with the pattern of kin-group competition. Hildred Geertz and Clifford Geertz, Kinship in Bali (Chicago: University of Chicago Press, 1975).

96 A similar argument has been made for the PKI in Java in the late 1940s. Mortimer writes, for example, that during the Revolution the PKI's "... access to the peasantry (such as it was) seems predominantly to have been via channels of patronage, kinship and traditional influence." Mortimer, "Class, Social Cleavage, and Indonesian Communism," pp. 6-7.

97 Carol Warren, "Balinese Political Culture and the Rhetoric of National Development" (typescript, 1988).

98 These are articulated most succinctly by Ernst Utrecht, a former PNI official in Bali, but similar arguments have found their way into much that has been written about Balinese politics in this period. See Utrecht, "Het bloedbad op Bali," De Groene Amsterdammer, January 14, 1967. 
we should accept the existence of a clutch of triwangsa as indicative of the general class composition or character of the PKI in Bali.

Similarly, the fact that within the PNI and among the post-coup killers there were, in the words of PNI-Bali leader Ernst Utrecht, "ordinary people" (gewone volk) and "small farmers" (kleine boeren), does not constitute compelling evidence of the fundamental class character of the PNI. To speak of the class character of any party is to speak of a general or essential pattern, both sociologically and ideologically. It is not an empirical claim that all members belong to a single, narrowly defined, socio-economic stratum.

The second argument advanced to demonstrate the ostensible political insignificance of class in the PKI-Bali is that the sociological basis for the PKI simply did not yet exist there. Utrecht writes:

Sociologically speaking, there was no reason to establish a branch of the PKI in Bali, because the social conditions for it did not exist there. ${ }^{99}$

According to this logic, the PKI in Bali was nothing more than a vehicle for a mixed bag of political opportunists and power grabbers; "people and groups who, for one reason or another had an axe to grind with members of the PNI." The mobilization of the rural population by the BTI, likewise, is portrayed as the irresponsible provocation of an otherwise harmonious and happy peasant community. In order to make this position stick, Utrecht paints a picture of Balinese social harmony and economic well-being which is reminiscent of the prewar travel fantasies which depict Bali as the "last paradise." He writes, for example, that "in the Balinese banjar ... there is little difference between rich and poor, and there is no unemployment." The tradition of mutual assistance (gotong royong), he assures us, is still strong, and forms the basis of all social interaction. Consequently, ". . no one goes hungry, and there is no real rural proletariat." In the towns the banjar institution remains unchanged, and for this reason "... none are left to their fate by the community. That is to say, there is no real urban proletariat." The evidence provided in the current article should leave little doubt that this portrayal is substantially untrue. It remains to be seen, however, to what extent and in what ways economic and class interest did intersect with political affiliation.

\section{Class and Political Affiliation}

The available evidence suggests that it was the poorest and the most land-hungry farmers, and agricultural laborers, who became members of the BTI in Bali after 1963. This is a pattern which makes intuitive sense, and which accords better with the facts of BTI militancy, than do existing portrayals of the PKI and BTI organization in Bali as a superficial mask for "traditional" social groupings. It was, moreover, a pattern which was deliberately fostered by BTI tactics which included the distribution of clothing, food, and promises of land to the poorest and the most vulnerable. ${ }^{100}$ The membership of the PNI peasant organization, Petani, was more heterogenous in class terms, perhaps reflecting the continued use of vertical mobilization strategies within the PNI. Petani members included relatively prosperous land-owning peasants, but also poorer tenant farmers who remained socially bound and economically dependent on landlords affiliated to the PNI.

The differences between the BTI and Petani were highlighted and accentuated during the land-reform campaign. While Petani and the BTI both officially supported the land reform, there were clear differences in the seriousness and the militancy of their efforts, and in

99 This and subsequent quotations in this paragraph are from Utrecht, "Het bloedbad op Bali."

100 Putra, "Pelaksanaan Landreform," pp. 58-59. 
the social classes to which they appealed. For example, while the BTI openly advocated a policy of "Land to the Tiller," Petani (like the PNI) emphasized prosperity, security, unity, and upholding Pancasila. A few examples from different parts of the island provide some sense of the different patterns of BTI and Petani membership and mobilization, which developed in the context of the land-reform campaign.

In Tejakula (Buleleng), a poor district with a high rate of tenancy and a large number of migrant laborers from neighboring Karangasem, the PKI and BTI became very popular with the "little people" (rakyat kecil) in the early 1960s. According to the Punggawa at that time, himself a PNI man and ex-pemuda, the PNI came to be seen there as a party of the landlords (tuan tanah), and suffered a serious loss in membership to the PKI after 1963.101 With the decline of the PNI, an opportunity was created for some PNI-affiliated peasants to migrate to the PKI and the BTI. The more prosperous peasants, however, tended to remain with Petani. Similarly, in Karangasem, the popularity of the PKI and the BTI with migrant laborers and small tenant farmers reportedly increased dramatically after the start of the aksi sepihak campaign in $1963 .{ }^{102}$

Within a given village, the hamlets with the largest BTI memberships, it would appear, were those with the greatest number of agricultural laborers and poor peasants, and relatively few middle and rich peasants. ${ }^{103}$ In a village in West Buleleng, for example, the BTI branch was organized and led by a landless agricultural laborer early in 1965, and all of its members were either poor peasants or agricultural laborers. In Mengwi, the two poorest hamlets were almost entirely PKI and BTI, while the other hamlets in the village were more or less equally divided politically between the PNI/Petani and the PKI/BTI. ${ }^{104}$ Finally, in Tabanan, according to the former regional head of Petani, the BTI was strongest in those areas with the largest numbers of landless peasants and agricultural laborers, while Petani's strength was in the relatively prosperous areas. ${ }^{105}$

A closer look at the relations of production in Tabanan provides some additional clues to the source of Petani's strength there, and to the relative weakness of the BTI. In 1963, the percentage of very small holdings in Tabanan was 44 percent, or less than the average for Bali (54 percent); in other words, this was an area of relatively large average farm size. To be sure, Tabanan had its share of landless and poor tenant farmers who stood to gain from the land reform, and many appeared to have gravitated to the PKI and BTI. However, it had a much greater number-in absolute and percentage terms-of prosperous landowning peasants and landlords, in a position to lose as a consequence of land reform. This contention is supported by the figures in Table 7 which show that Tabanan had the highest percentage of owner-operated farms ( 73 percent), and conversely the lowest level of tenancy anywhere in Bali. ${ }^{106}$ It is also supported by a 1956 government report which indicates that, in that year, Tabanan had 81,537 landowners of a total for Bali of 384,925. This large group of relatively

101 Interview with Ida Bagus Indra (former-DPRI leader and former Punggawa Tejakula, 1961-1965), Singaraja, December 17, 1986. The district of Kubutambahan (Buleleng) was also a PKI stronghold, but here the social base of the party was less clear. According to Indra, who was Punggawa there 1966/67, many joined the PKI on the suggestion of the influential Gde Ngurah Intaran, a former Punggawa from the colonial period, who had not joined the Revolution.

102 Putra, "Pelaksanaan Landreform," p. 104.

${ }^{103}$ Slamet, "Views and Strategies of the Indonesian Peasant Movement,"pp. 127, 190.

104 Personal communication from Henk Schulte Nordholt, May 2, 1987.

105 Interview with I Gusti Putu Yasa Arimbawa, December 20, 1986.

106 Tabanan was followed by Badung with 75,004 and Gianyar with 62,811 landowners. Tindjauan Pasar Kerdja, p. 35. 
prosperous landowning peasants and small proprietors very likely formed the core of Petani's strength in Tabanan. ${ }^{107}$ The split between the BTI and Petani, then, was not simply between "tenants" and the largest "landlords," but reflected a more subtle gradation of class difference between, on the one hand, poor and landless tenants and, on the other, relatively prosperous, landowning peasants, which was accentuated by the land-reform campaign after 1963.

The implementation of the land reform appears also to have influenced the caste character of the BTI and PKI leadership, such that commoners became increasingly prominent after 1963. A rough survey of the names of hamlet and village level PKI and BTI cadres mentioned in press reports and other accounts from 1964 and 1965, reveals that very few indeed were triwangsa. Although, as noted above, caste status cannot be taken as an indication of class position, the small number of triwangsa does suggest that, in these years, the PKI and BTI in Bali were not relying heavily on "vertical alliance" strategies of mobilization. The PKI and BTI cadres were undoubtedly influential men and women, but on the whole they were not influential as a consequence of their caste status or their wealth. The emergence of such low-caste leaders at the local level could very well account for the radicalism and militancy of the BTI after 1963.

The evidence from Karangasem is revealing. In a place where feudal traditions remained strong, one might reasonably have expected to find the PKI employing a "vertical alliance" strategy. Yet in three areas with substantial PKI memberships in Karangasem-Sidemen, Ababi, and Antiga-the majority of local PKI and BTI activists were commoners. The only exception was in Sidemen where some-though not all-of the PKI cadres were of the Satria caste. ${ }^{108}$ Like many of the pemuda leaders during the Revolution, the popularity and credibility of PKI and BTI leaders in these areas appears to have depended far more on their ability as orators and organizers, their intelligence, their skill in martial arts (pencak silat), and their reputation for spiritual or magical powers, than on traditional prestige deriving from caste or aristocratic lineage. ${ }^{109}$

Despite this similarity with the revolutionary period, the politics and the economic conditions of post-revolutionary Indonesia had transformed the bases of political loyalty and party allegiance in Bali in the direction of greater class polarization. Thus, in two important base areas of the Revolution-Badung and Tabanan-where one might have anticipated stronger leftist tendencies, opposition to land reform and to the PKI was powerful. The paradox can be resolved by recalling the different configuration of social forces which supported the Revolution and the land reform. The social base of the Revolution encompassed a plurality of class positions and did not, as a whole, provide a natural base for the PKI, particularly as the party took an increasingly militant stand on land and economic issues. The alliance of social forces which together had provided the backbone of the Revolution in the

107 The strength of this group may help to explain the stiff resistance to land reform which was encountered there. Table 5 shows that of the three areas with the worst record of land redistribution as of mid-1964Tabanan, Gianyar, and Badung-Tabanan had: i) the largest absolute number of affected landowners; ii) the largest area of land slated for redistribution; and iii) the lowest level of redistributed land (26 percent of the area slated for redistribution).

108 Putra, "Pelaksanaan Landreform," pp. 124-26.

109 Ibid., pp. 51-52. In addition, many of the PKI and BTI leaders at the local level, about whom there is information, were either teachers or community leaders, such as hamlet heads (klian banjar) or village heads (kepala desa). The klian banjar appear to have been especially important in mass mobilization. While klian could be very influential within their community, their social and political position did not necessarily militate against radicalism. Ibid., pp. 58-59, 125. 
central regions-a relatively prosperous and autonomous peasantry, "progressive" elements of the aristocracy, a small indigenous capitalist class, an educated nationalist middle class, and a mixed bag of pemuda - could hardly have been expected to become the vanguard of a genuine social or agrarian revolution.

Yet, while it appears to have been important in transforming political affiliation and the character of political conflict in Bali, the political salience of class should not be overstated. In many instances, strong bonds of loyalty, or close religious or familial ties between landlords and tenants did serve to inhibit the movement toward class based consciousness and action. Furthermore, because landowners who were immediately threatened by the land reform often had substantial followings of clients and tenants, the effective size of the community which felt aggrieved by land reform actually spread far beyond those landlords who faced expropriation. This was particularly true in the eastern kingdoms where feudal relations remained deeply entrenched and very high rates of tenancy continued to prevail in the 1960s (See Table 7).

Thus, for example, a poor peasant who had for years cultivated a plot belonging to the local puri, might well have felt threatened by the redistribution of the puri's land, because he could not be sure that the new owner would permit him to remain on the land. Others may simply have felt that it was wrong or inappropriate to seize the land of one's lord. ${ }^{110}$ These kinds of influence tended to work to the advantage of the PNI and Petani in preventing a mass defection to the PKI and BTI along class lines. They also help to explain how bitter conflict could erupt not just between the wealthiest landlords and the most marginal tenants but also amongst relatively poor peasants themselves.

\section{The Political Dynamic of Conflict}

The political dynamic of conflict over land reform in Bali has yet to be analyzed in any depth. In general treatments of land reform, Bali is mentioned only parenthetically. Mortimer shows how conflict over land in Java was accelerated by, and found expression in, bitter antagonism between santri and abangan villagers, but he provides no parallel explanation of the logic of the conflict in Bali. Those who favored the land reform (and the PKI/BTI) in Bali, he refers to casually as abangan, but in Bali's very different religious and cultural environment such a designation is of questionable value. ${ }^{111}$ The result is that the violent political conflict of the mid-1960s continues to be seen either as a foregone conclusion-because Balinese politics are understood simply to have reflected developments on Java - or as some sort of mystery, decipherable only in terms of Bali's unique culture. What is needed, clearly, is an explanation of the political conflict over land in Bali which takes into account both the cultural specificities of the island as well as the political and structural forces with which these interacted. The analysis which follows pays particular attention to the latter because they have been less frequently treated in works on Bali.

110 In one such case, reported from Sidemen, Karangasem, a peasant (I Wayan Pugleg) refused to join the BTI at a public meeting, despite a promise that, as a member, he would get to own the puri-owned land that he cultivated. According to others who attended the meeting, Pugleg refused on the grounds that it would "not be fitting to oppose the royal family since he himself had long been a dependant of the puri." Putra, "Pelaksanaan Landreform," p. 112.

111 Mortimer, "Class, Social Cleavage, and Indonesian Communism," p. 18. 


\section{A State Divided}

The implementation of the land-reform legislation began officially in Bali on January 1 , 1961. The first phase of the process involved the formation of Land-reform Committees (Panitya Land-reform), Land Registration Committees (Panitya Pendaftaran Tanah), and Working Bodies (Badan Pekerdja) at the kabupaten, kecamatan, and village level. The committees were first to oversee the registration of excess land, and then to make the politically sensitive decisions about what land was to be redistributed, and to whom. The composition of the committees ensured that government officials played a preponderant role in making these controversial decisions. ${ }^{112}$ Particularly powerful were the Bupati, who served as Chairmen of the kabupaten-level Land-reform Committees, and who oversaw the formation of the committees at lower levels. ${ }^{113}$ Representatives of the farmers' organizations, and of other mass organizations, also served on the committees and Working Bodies, though they were less numerous and initially less powerful.

These arrangements worked to the advantage of the PNI (and ex-PSI) whose members still held a dominant position within most of the kabupaten-level bureaucracies in Bali. One consequence was that, as in Java, the implementation of the land-reform legislation proceeded very slowly for at least the first two years. By mid-1963, for example, not a single formal harvest-sharing agreement had been completed in accordance with the provisions of the 1960 law. The process of land registration was also proceeding at a snail's pace with the result that very little land had been redistributed by mid-1963. The situation changed dramatically in the latter half of 1963, when the land-reform legislation became the focus of the PKI's rural mass mobilization campaign; and won the backing of Sukarno and key elements within Bali's state apparatus. With this shift, the land reform began to be implemented far more vigorously and, as a consequence, it came to represent a genuine threat to landed interests, and to their backers in the PNI.

Governor Sutedja's support of land reform was particularly important. Shortly after the PKI leadership declared its mass mobilization plans, Sutedja began to issue executive orders calling for the rapid completion of land redistribution. ${ }^{114}$ In August 1963 he initiated competitions for implementing the law on harvest sharing, to encourage tenants to take full advantage of their rights. And in 1964 he threatened legal action against Land-reform Committees which continued to drag their feet. ${ }^{115}$ Within the provincial administration, Sutedja worked to ensure that key positions were filled by people supportive of radical land reform. His Chief Agricultural Inspector for Bali, Soembadi, for example, was known to be

112 At the kabupaten level, the Land-reform Committees had the following composition: Chairman-Bupati; Vice-Chairman-Head of the Office of Agrarian Affairs; Vice-Chairman-Head of the "Front Nasional"; Members-Commander of the Regional Military Command, Head of the Police Resort Command, Head of the kabupaten office of the Ministry of Justice, Vice-Chair of the DPRGR, head of the Office of Land Registration, head of the Office of Agriculture, head of the Office of Livestock, head of the Office of Irrigation, head of the Cooperatives Service, head of the Office of Labor and Public Works, head of the Office of People's Industries, head of the Land-tax Office, head of the Office of Religion, branch head of the Farmers and Fishermans Cooperative Bank, representatives of the mass organizations, delegates proposed by the National Front to represent the different elements of NASAKOM. Putra, "Pelaksanaan Landreform," pp. 68-69.

113 Among their other powers, the Bupati were given the authority to determine the precise terms for the division of harvest within their region.

114 For a sense of Sutedja's stance on land reform see, "Titik Tolak Giatkan Pelaksanaan UUP Agraria Selesaikan Revolusi," Suara Indonesia (Denpasar), September 25, 1962; and "Pd. Gub. Bali-Pengakuan Lebih Tegas Thd. Tani dan Buruh Sbg. Soko-gurunja Revolusi," Suara Indonesia (Denpasar), September 25, 1964.

115 See, for example, "Bali Harus Mampu Menjelesaikan Landreform Belum September Ini," Suara Indonesia (Denpasar), May 17, 1964. 
sympathetic. Sutedja was also instrumental in overcoming local-level resistance by the PNI and landlords who dominated many of the kabupaten and kecamatan-level Land-reform and Land Registration Committees, and who were, on the whole, far less enthusiastic about land reform than the national PNI leadership. ${ }^{116}$ Joel Rocamora writes that, in Bali:

PNI control over local administration proved of no avail with a Governor apt to cancel the decisions of pro-PNI local administrators. By late 1964, the confrontation between the two parties over the land problem was so intense that armed clashes had become a frequent occurrence. ${ }^{117}$

Because excess land was to be taken by state authorities and then redistributed, the landreform system depended critically on the belief that the authorities would act impartially in both expropriation and distribution. Yet by 1963 the political divisions within the state apparatus in Bali were so evident that there was serious and legitimate concern about its impartiality. Governor Sutedja's support for radical land reform, while it was effective in some areas, therefore also fueled polarization and violence at the local level. By refusing to order police intervention in the event of aksi sepihak confrontations, for example, Sutedja appeared to lend his support to the PKI. This, in turn, encouraged activists of the PNI and its peasant organization, Petani, to take direct action, rather than to rely on the "state" to intervene. The leader of Petani in Tabanan described the logic of such direct action as follows:

None of the police had the courage to act unless they had the go-ahead from Sutedja. If Sutedja said nothing, they did nothing. And so we had no choice but to fight it out right there. One time the BTI leader said to me-Why don't we sit down and negotiate? I said-Forget it! Denpasar is the place for negotiations. Here we fight to see who wins!118

PKI and BTI militancy was similarly stimulated by the obstructive behavior of PNI and landlord-dominated Land-reform and Land Registration Committees.

In accordance with their political and economic interests, party and government officials took advantage of elements of the state apparatus at their disposal either to obstruct or to promote the distribution of land. The pace of implementation of the land reform therefore varied from one kabupaten to the next, depending in part on the political complexion of the executive in each area. In Jembrana and Buleleng, which had a relatively high proportion and absolute number of large landowners, one might have expected stiff opposition to the land reform (See Table 4). Yet the redistribution of land was almost complete there by the time of the coup. The success of the land reform in these two kabupaten was attributable, in large measure, to the existence of pro-PKI/Partindo elements in the local administration, such as the Bupati I.B.M. in Buleleng and I.B.D. in Jembrana. ${ }^{119}$ By contrast, in areas such as Badung and Gianyar, the position of anti-land reform forces was, at least until the end of

116 In Jakarta the PNI leadership seemed to support the land-reform legislation with some enthusiasm. As Rocamora argues, however, the position of local PNI leaders was considerably more conservative. J. Eliseo Rocamora, "Nationalism in Search of an Ideology; Indonesia's Nationalist Party 1946-1965," PhD Dissertation, Cornell University, 1974, pp. 528-29.

117 Ibid., p. 530. Estimates of the numbers killed in these pre-coup conflicts, range from 100 to 500 . A limited survey of pre-coup clashes in Bali can be found in Universitas Gajah Mada, Pusat Penelitian dan Studi Pedesaan \& Kawasan, Keresahan Pedesaan Pada Tahun 1960-an, 1982, pp. 93-95.

118 Interview with I Gusti Putu Yasa Arimbawa (former head of Petani-Tabanan), Tabanan, December 20, 1986. 119 The Bupati of Buleleng was widely believed to belong to Partindo. Like Sutedja and Sukarno, however, he claimed to be non-party, and explicitly denied affiliation with Partindo. See, "Bupati M: Saja Bukan Partindo," Suara Indonesia (Denpasar), May 19, 1964. 
1964, bolstered by the existence of long-standing PNI (and ex-PSI) kabupaten administrations (See Table 8). The result was a determined and powerful opposition to land redistribution within the state itself. ${ }^{120}$

In the course of implementation, then, there was a good deal of leeway for political meddling by bodies which were ostensibly organs of the state, for example: in the process of land registration; the determination of which holdings were in excess of the legal maximum and which landlords were considered to be absentee owners; and in the selection of recipients of redistributed land. ${ }^{121}$ A February 1964 report to Bali's legislature (DPRD-GR) specifically mentioned the kabupaten-level Land-reform Committees, kabupaten-level Land Registration Committees, and the Agrarian Affairs Inspectorate, as loci of political manipulation.

Table 8. The Bupati of Bali and Their Political Affiliation, 1964/65

\begin{tabular}{llc}
\hline \hline Kabupaten & \multicolumn{1}{c}{ Bupati's Name } & Party Affiliation \\
\hline Buleleng & I.B.M. & Non-Party/Partindo \\
Jembrana & I.B.D. & PKI \\
Tabanan & Ida Bagus Puja & PNI \\
Badung & I.G.N.A. Patjung-to November 1964 & PSI \\
& A.A.G.A. early 1965 & PKI \\
& I Wayan Dhana-late 1965 & PNI \\
Gianyar & Tjokorda Ngoerah-to November 1964 & PSI \\
& I.M.S.-to November 1965 & PKI \\
Bangli & Ida Bagus M. Sutha & PNI \\
Klungkung & Tjokorda Anom Putra & PNI \\
Karangasem & Tjokorda Lanang Rai & PNI \\
\hline
\end{tabular}

Local committees could and did cooperate with landlords by under-reporting actual holdings, or by warning them ahead of time to adjust the records of their holdings. A common tactic for avoiding the confiscation of one's land was to divide it up among kin, or loyal allies, thereby bringing each individual holding within the legal maximum. ${ }^{122}$ The committees seldom went to the field to verify the information provided by landowners, who were therefore free to misreport the exact size or location of their holdings. In some cases they also lied about the identity of the tenant, so that when their land was redistributed, it would go to a close friend or relative rather than to the tenant farmer entitled to it by law. ${ }^{123}$

120 The political balance changed in late 1964 when pro-PKI Bupati were appointed in both Badung and Gianyar for brief periods. In 1965, Gianyar had a PKI Bupati, I.M.S., but his base within the local administration was not well established. He was removed from office on November 8, 1965, only a few days after the "freezing" of the PKI in Bali.

121 See Putra, "Pelaksanaan Landreform." Instances of cheating and foot-dragging were reported frequently in the local press, particularly in 1964, when most of the actual transfers took place. See, for example, the following articles in Suara Indonesia (Denpasar): "Petani Ketjil Jang Dirugikan," March 6, 1964; "Selesaikan Landreform Setjara Djudjur,"March 20, 1964; "Banjak Faktor-Faktor Negatif Jang Menghambat Djalannja Landreform di Bali," June 10, 1964; "Feodal Keraton Tuan Tanah Kepala Batu," October 2, 1964.

122 Interview with Ida Bagus Indra (former Punggawa), September 30, 1986.

123 Putra, "Pelaksanaan Landreform," pp. 89-90. 
Other tactics for subverting the land reform "from within" included the falsification of deeds and titles and deliberate foot-dragging in carrying out the bureaucratic and legal formalities involved in the transfer of ownership. The following situation, for example, was reported in Singakerta, Gianyar:

One aristocratic family had formally divided up the land among kin, sharecropping going on as usual, other plots had been illegally sold to the village head, who then sharecropped them out to farmers, instead of the plots being surrendered to the original sharecroppers. Some sharecroppers had indeed received in ownership the land they tilled after paying off the compensation sum, but official certificates were withheld by the village head, or anyway no efforts were made by him to obtain an official confirmation of the transaction from the Ministry. ${ }^{124}$

Landlords also used the court system to challenge the decisions of the Land-reform Committees and to hold up the actual transfer of their land. ${ }^{125}$ These tactics had important long term consequences. The filing of charges before the courts and the failure to complete legal transactions meant that land transfers remained unresolved and were legally open to dispute. When the political balance shifted against the PKI and BTI in late 1965, the process of reclaiming lost land was therefore relatively simple.

\section{Mass Action}

The existence of party-affiliated peasant organizations in virtually every village and hamlet on the island contributed to the dynamic of conflict in rural areas. Although the vast majority of BTI branches developed in late 1964 and 1965, the organization quickly gained a reputation for unusual militancy and radicalism, emphasizing the principle of "land to the tiller." As noted earlier, local BTI activists in Bali, like their counterparts in Java, appear to have gone well beyond a strict interpretation of the land-reform laws, thereby accentuating conflict. In Karangasem, for example, some BTI members reportedly demanded a 2/3 share of the harvest for tenants on sawah, with some proportion of that share to go to the PKI. This kind of harvest-sharing arrangement was apparently promised by BTI activists at public meetings in several villages throughout Karangasem, and very likely in other parts of Bali as well. ${ }^{126}$

Mass political action in Bali took a variety of forms, of which the most notorious were the aksi sepihak, or the unilateral, and sometimes forceful, seizure of land by PKI/BTI farmers. ${ }^{127}$ Also known as pendobrakan in Bali, such actions are known to have occurred throughout Karangasem, Badung, Tabanan, Buleleng, and Jembrana, and probably took place in other areas as well. ${ }^{128}$ Though the ultimate target of the aksi sepihak was usually the

124 Slamet, "Views and Strategies of the Indonesian Peasant Movement," p. 92.

125 Putra recounts the case of I Serimadi and his relatives, who owned land in Karangasem but had resided in Buleleng for several years. The Land-reform Committee in their kabupaten in Karangasem judged them to be absentee landlords. However, the family took the case to court and won. Putra, "Pelaksanaan Landreform," pp. 91-94.

126 Putra mentions BTI rallies along these lines in the following villages in Karangasem: Padangbai, Sangkan Gunung, Bunutan, and Ababi. Ibid., pp. 102-103.

127 For specific instances of aksi sepihak see the following reports in Suara Indonesia (Denpasar): "Jang Bertindak Diluar Ketentuan Agar Ditindak," September 18, 1964; "Demonstrasi Sarbupri-BTI di Perkebunan JKP Sendang," October 16, 1964; "Aksi Sepihak Kita Ganjang Dengan Aksi Bersama," November 4, 1964.

128 More details are available for Karangasem than for other areas. Putra identifies several individual villages as sites of aksi sepihak: Sideman, Ababai, Tanah Ampo, Gegelang, Ulakan, Sangkan Gunung, Yang Taluh, Bug, and 
land of the largest landowners-and quite often that of the local puri-the immediate victim of the action was not infrequently a tenant farmer who cultivated the plot. In one case, reported from Karangasem, a group of about 40 BTI supporters from Desa Rendang marched with flags and banners to seize a piece of sawah in Desa Sungkan Gunung, owned by the puri Karangasem. The tenant farming the land in question, a certain I Wayan Kenggo, was in his field when the group arrived, and he reportedly died resisting their attempt to seize the land. ${ }^{129}$ In a similar case in Yang Taluh, Sidemen, the land in question was also owned by the puri Karangasem, but the tenant, I Wayan Madra, was supported by other PNI farmers and was not killed by the BTI group. ${ }^{130}$

Whether there were deaths or not, incidents such as these inevitably generated even greater conflict in the countryside and sent people to one party or another, at least in part for protection and to seek revenge. And although BTI members were often motivated by a common class interest, the complexity of rural class relations meant that one's "class enemies" might include other poor farmers or tenants who appeared to collaborate too closely with their landlords. Thus, the groundwork was laid for deep bitterness and conflict to develop not only between landlords and tenants but also among Bali's poorest tenant farmers.

In addition to the aksi sepihak there were a variety of other forms of mass action employed by the BTI and Petani, which contributed to the dynamic of political conflict in the countryside. Both PKI/BTI and PNI/Petani organizers deliberately held rallies and marches in "enemy" territory, carrying banners and flags, shouting slogans, and singing songs. A marching song sung by PKI/BTI members in Sideman (Karangasem) went like this:

We swear an oath of equality

Poverty will surely end

Farmers and workers will all have work

A new world will surely come

Come, come take action now

Freedom is already ours

Our flag is red

And red is the color of the blood of the people

Red is the color of the blood of the people. ... 131

On occasion, hundreds of members of each organization would join in massive shouting matches. BTI members would shout, for example, "Hancurlah Tuan Tanah!" ("Destroy the Landlord!"), while Petani supporters would respond with "Marhaen! Marhaen!" Other forms of action included: burning government offices, stoning the houses of political opponents, and deliberately disrupting a religious ceremony or community meeting. Physical scuffles and armed attacks resulting in death were not uncommon.

Particularly bitter confrontations developed over BTI occupations of religious (pura) lands, and land attached to one of the more powerful puri. Unilateral BTI seizures of such lands were construed by their opponents as sacrilege, as challenges to the Bali-Hindu religion, and as disruptive of the cosmic order. Also considered offensive and sacrilegious were the refusal by some PKI and BTI members to abide by linguistic etiquette in dealings with

Nyuhtebel. According to Putra, many of the aksi sepihak were directed against land owned by the puri

Karangasem. Putra, "Pelaksanaan Landreform," pp. 109, 112.

129 Ibid., p. 110.

130 lbid., p. 116.

131 Ibid., p. 105. 
their "superiors," or their failure to perform customary ritual obligations within the banjar, the subak, or some other community of which they were a member. Such interpretations were powerfully reinforced by natural calamities, like the eruption of Gunung Agung in 1963, and the wave of rat and other pest plagues which swept the island, both of which were viewed by many as supernatural confirmation of a cosmological imbalance and spiritual impurity. And because these natural disasters coincided almost exactly with the most militant and aggressively class-based PKI and BTI actions, it was plausible to argue that these actions, and those who initiated them, were responsible for the imbalance.

As in parts of Java, the manner in which class interests dovetailed with certain cultural sensibilities helps to explain the intensity of political conflict in Bali. If in East Java the significant cultural division was between Muslim santri (associated with the Nahadatul Ulama) and abangan (affiliated with the PKI), in Bali where the vast majority were Hindu, the relevant distinction was, broadly speaking, between those who wished strongly to preserve existing social relations and religious institutions, and those who wished to see significant changes in both, in the direction of greater democracy, meritocracy, and egalitarianism. And just as the "cultural" conflict between santri and abangan in East Java overlapped with a class-based conflict between landlords and poor peasants, so in Bali the conflict between cultural conservatives and iconoclasts was, to some extent, isomorphic with conflict based on class interests.

\section{Conclusions}

Whereas in the 1950s political party followings were amorphous cross-class affairs, by 1965 the two major parties (the PNI and the PKI) had each developed a more distinctive class character. In addition to economic scarcity and runaway inflation, changes in local class formation-in particular the emergence of a significant pool of wage-earners and unemployed in the towns, the development of a political consciousness among Bali's landhungry and tenant farmers, and the emergence of a small but influential group of Balinese entrepreneurs-added a new dimension to political relations, and led to a much greater polarization on class lines in the early 1960 s. By 1965 , the PNI was seen as the party of the local "national" capitalist class, civil servants, large landlords, relatively prosperous peasant landholders, a still influential aristocracy, and those peasants dependent upon them. The constituency of the PKI and the Partindo included landless and tenant farmers, the urban underclass, school-teachers, a proportion of the educated middle class, and some progressive members of the old aristocracy.

Especially important in this transformation was the way in which national economic policies and developments were articulated in Bali through the local state apparatus and the political party system. Despite its financial dependence on the center, Bali's local state powerfully influenced class formation, political party alignment, and conflict. Through a "nationalist" economic policy, which included the granting of licenses and contracts to selected entrepreneurs, the state encouraged the formation of a class of Balinese capitalists. The dependence of the new capitalist class on the patronage of the local state and the PNI, meant that it had reason to be worried when, in the early 1960s, political control of the state moved steadily to the left and out of PNI hands. In alliance with the PNI, this new class sought to recoup its losses in the aftermath of the 1965 coup.

Perhaps even more important politically was the role of the local state in support of land reform after 1963. Strong intervention on behalf of radical land reform by key figures in the national and local state apparatus in Bali, meant that the interests of landowners, and the 
political parties that supported them, were genuinely threatened. This fact lay behind the intransigent and reactionary attitude of the largest landlords and the PNI. Those threatened by, or unlikely to benefit from, the land reform also included a substantial number of relatively prosperous landowning peasants, concentrated in the chief rice-growing regions of Tabanan and Badung. Using their still considerable power in Bali's legislative and executive bodies, these forces together offered strong resistance to land reform, contributing to political conflict along class lines in the countryside.

The process of political polarization was accelerated by the mobilization of mass peasant organizations affiliated to the two major political parties. In some areas, the strength of economic and cultural ties between landlords and tenants slowed the process of class polarization, so that conflict developed not only between landlords and tenants but also among poor peasants and tenants. Once it had begun, however, the competition between the BTI and Petani members appeared to take on its own momentum, leading to physical confrontations and sometimes killings. The overlapping effect of class interests and cultural sensibilities further accentuated the conflict, and laid the basis for the intense violence of 1965/66.

The aggressiveness of the BTI's land-reform campaign, the relative success which it achieved in redistributing land, and the way in which class interest coincided with cosmology, proved an explosive combination. It appears likely - though difficult to confirm-that the severity of the violence after October 1965, was in proportion to the radicalism of the land-reform campaigns in 1963-1965. In Jembrana and Buleleng, for example, where the land reform was nearly complete by 1965 , the post-coup violence was extreme. Similarly, in Karangasem, where the BTI had been especially aggressive and land reform had led to very serious disputes in 1964 and 1965, the violence was widespread.

The emphasis on economic and class issues provided in this article has been intended, in part, as an antidote to conventional wisdom. This is not to say that the political struggles and violence of the 1960s in Bali can be properly understood as a matter of "class-war," or that class consciousness superseded all other cultural or religious attachments. That is clearly not the case. But the time has surely come to look more seriously at how class intersts and economic issues transformed Balinese politics and laid the basis for the violence of $1965 / 66$.

In this regard it is important to remember that the still widely accepted arguments regarding the "insignificance" of class in Bali come straight from the PNI manual. The denial of the political salience of class, the claim that the PKI had no real mass base, the effort to depict PKI leaders as mere political opportunists, the view that Balinese were more interested in maintaining harmonious community relations than in fighting for class interests; these were all part of the ideological and political arsenal of the PNI in Bali in the mid-1960s. As such, they ought not to be accepted uncritically as good history or good sociology. My sense is that much of what has been written about politics in Bali under the Old Order has been based on precisely these sorts of unexamined arguments. In other words, we have come to know, and to believe, only the victor's version of history. 
